\title{
Quantifying atmospheric nitrate formation pathways based on a global model of the oxygen isotopic composition $\left(\Delta^{17} \mathrm{O}\right)$ of atmospheric nitrate
}

\author{
B. Alexander ${ }^{1}$, M. G. Hastings ${ }^{2}$, D. J. Allman ${ }^{1}$, J. Dachs ${ }^{3}$, J. A. Thornton ${ }^{1}$, and S. A. Kunasek ${ }^{4}$ \\ ${ }^{1}$ Department of Atmospheric Sciences, University of Washington, Seattle, WA, USA \\ ${ }^{2}$ Department of Geological Sciences and Environmental Change Initiative, Brown University, Providence, RI, USA \\ ${ }^{3}$ Department of Environmental Chemistry, Institute for Environmental Assessment and Water Studies (IDAEA-CSIC), \\ Consejo Superior de Investigaciones Científicas, Barcelona, Spain \\ ${ }^{4}$ Department of Earth and Space Sciences, University of Washington, Seattle, WA, USA
}

Received: 15 April 2009 - Published in Atmos. Chem. Phys. Discuss.: 5 May 2009

Revised: 18 July 2009 - Accepted: 18 July 2009 - Published: 28 July 2009

\begin{abstract}
The oxygen isotopic composition $\left(\Delta^{17} \mathrm{O}\right)$ of atmospheric nitrate is a function of the relative abundance of atmospheric oxidants $\left(\mathrm{O}_{3}, \mathrm{RO}_{\mathrm{x}}=\mathrm{OH}+\mathrm{HO}_{2}+\mathrm{RO}_{2}\right)$ and the formation pathway of nitrate from its precursor $\mathrm{NO}_{\mathrm{x}}$ $\left(=\mathrm{NO}+\mathrm{NO}_{2}\right)$. Coupled observations and modeling of nitrate $\Delta^{17} \mathrm{O}$ can be used to quantify the relative importance of chemical formation pathways leading to nitrate formation and reduce uncertainties in the budget of reactive nitrogen chemistry in the atmosphere. We present the first global model of atmospheric nitrate $\Delta^{17} \mathrm{O}$ and compare with available observations. The largest uncertainty for calculations of nitrate $\Delta^{17} \mathrm{O}$ is the unconstrained variability in the $\Delta^{17} \mathrm{O}$ value of tropospheric ozone. The model shows the best agreement with a global compilation of observations when assuming a $\Delta^{17} \mathrm{O}$ value of tropospheric ozone equal to $35 \%$ o and preferential oxidation of $\mathrm{NO}_{\mathrm{x}}$ by the terminal oxygen atoms of ozone. Calculated values of annual-mean nitrate $\Delta \Delta^{17} \mathrm{O}$ in the lowest model layer $(0-200 \mathrm{~m}$ above the surface) vary from $7 \%$ in the tropics to $41 \%$ in the polar-regions. The global, annual-mean tropospheric inorganic nitrate burden is dominated by nitrate formation via $\mathrm{NO}_{2}+\mathrm{OH}(76 \%)$, followed by $\mathrm{N}_{2} \mathrm{O}_{5}$ hydrolysis (18\%) and $\mathrm{NO}_{3}+\mathrm{DMS} / \mathrm{HC}(4 \%)$. Calculated nitrate $\Delta^{17} \mathrm{O}$ is sensitive to the relative importance of each nitrate formation pathway, suggesting that observations of nitrate $\Delta^{17} \mathrm{O}$ can be used to quantify the importance of individual reactions (e.g. $\mathrm{N}_{2} \mathrm{O}_{5}$ hydrolysis) leading to nitrate formation if the $\Delta^{17} \mathrm{O}$ value of ozone is known.
\end{abstract}

Correspondence to: B. Alexander (beckya@u.washington.edu)

\section{Introduction}

The formation and cycling of reactive nitrogen in the atmosphere has important implications for air quality, the oxidation capacity of the atmosphere, and atmospheric nitrate (nutrient) deposition. Combustion of fossil fuels, biofuels, and biomass and lightning converts or "fixes" inert nitrogen gas $\left(\mathrm{N}_{2}\right)$ into a highly reactive form $\left(\mathrm{NO}_{\mathrm{x}}=\mathrm{NO}+\mathrm{NO}_{2}\right)$. Other sources of $\mathrm{NO}_{\mathrm{x}}$ to the atmosphere include microbial processes in soils and transport from the stratosphere (Logan, 1983). Anthropogenic activities currently dominate $\mathrm{NO}_{\mathrm{x}}$ sources to the troposphere (Jaeglé et al., 2005). The influence of human activities on the atmospheric nitrogen budget is evident in the record of increasing nitrate concentrations over the past $\sim 100$ years in Greenland ice cores (Mayewski et al., 1990).

The photochemical cycling of $\mathrm{NO}_{\mathrm{x}}$ leads to the formation of tropospheric ozone $\left(\mathrm{O}_{3}\right)$, a major air pollutant. Tropospheric ozone and its byproduct, the hydroxyl radical $(\mathrm{OH})$, largely determine the oxidizing capacity of the atmosphere and the lifetime of most reduced trace gases (Thompson, 1992). The formation of nitrate, defined herein as gas-phase $\mathrm{HNO}_{3}$ plus particulate $\mathrm{NO}_{3}^{-}$, is the main sink of $\mathrm{NO}_{\mathrm{x}}$ in the atmosphere. Nitrate is soluble and is lost from the atmosphere through wet and dry deposition to the Earth's surface, providing a nutrient source to many ecosystems (Galloway et al., 2008).

Figure 1 summarizes the chemistry of $\mathrm{NO}_{\mathrm{x}}$ cycling and nitrate formation in the atmosphere. Upon emission, $\mathrm{NO}_{\mathrm{x}}$ cycles rapidly during the daytime between $\mathrm{NO}$ and $\mathrm{NO}_{2}$ via oxidation (Reactions R1-R3) and photolysis (Reaction R4).

Published by Copernicus Publications on behalf of the European Geosciences Union. 


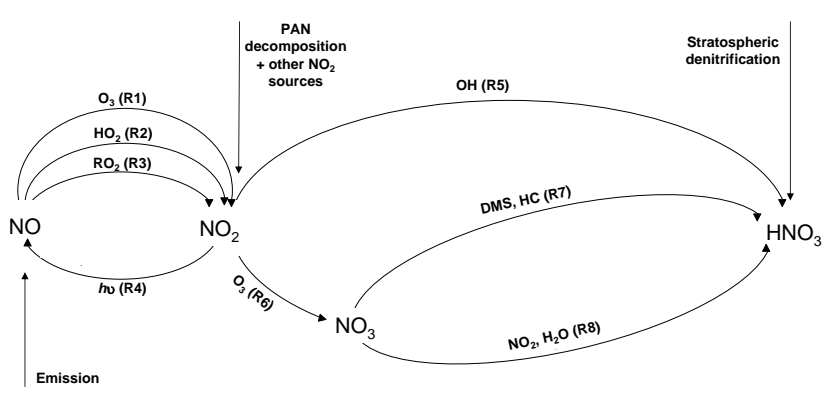

Fig. 1. Simplified chemistry leading to inorganic nitrate formation in the model.

$\mathrm{NO}$ is oxidized to $\mathrm{NO}_{2}$ by ozone $\left(\mathrm{O}_{3}\right)$ (Reaction $\mathrm{R} 1$ ) and peroxy radicals $\left(\mathrm{HO}_{2}\right.$ and $\left.\mathrm{RO}_{2}\right)$ (Reactions $\mathrm{R} 2-\mathrm{R} 3$ ). $\mathrm{NO}_{2}$ is also produced through decomposition or oxidation of peroxyacyl nitrates (PANs), reactions of peroxy radicals $\left(\mathrm{RO}_{2}\right)$ with peroxynitrates $\left(\mathrm{RO}_{2} \mathrm{NO}_{2}\right)$ and alkyl nitrates $\left(\mathrm{RONO}_{2}\right)$, and oxidation or decomposition of nitrous acid (HONO), pernitric acid $\left(\mathrm{HNO}_{4}\right)$, nitrate radicals $\left(\mathrm{NO}_{3}\right)$ and dinitrogen pentoxide $\left(\mathrm{N}_{2} \mathrm{O}_{5}\right) . \mathrm{NO}_{2}$ is lost from the atmosphere through oxidation and dry deposition to the surface. $\mathrm{NO}_{2}$ is oxidized by $\mathrm{OH}$ (daytime) to form $\mathrm{HNO}_{3}$ (Reaction R5) or by $\mathrm{O}_{3}$ to form $\mathrm{NO}_{3}$ (Reaction $\mathrm{R} 6$ ). $\mathrm{NO}_{3}$ is rapidly photolyzed during the daytime, so that $\mathrm{NO}_{3}$ concentrations are only significant at night. At night, $\mathrm{NO}_{3}$ reacts with dimethylsulfide (DMS) or hydrocarbons (HC) (Reaction R7) or with $\mathrm{NO}_{2}$ to form $\mathrm{N}_{2} \mathrm{O}_{5}$ followed by hydrolysis on the surface of aerosols (Reaction R8) to form $\mathrm{HNO}_{3}$. The lifetime of $\mathrm{NO}_{\mathrm{x}}$ against conversion to $\mathrm{HNO}_{3}$ in the boundary layer varies from $\sim 1$ day (tropics and in summer in the mid-to-high latitudes) to $\sim 3$ days (high latitudes in winter) (Levy et al., 1999). Nitrate is lost from the atmosphere mainly through wet and dry deposition.

The oxygen isotopic composition of nitrate reflects the relative importance of different oxidants in $\mathrm{NO}_{\mathrm{x}}$ cycling and nitrate formation (Michalski et al., 2003; Hastings et al., 2003). Atmospheric nitrate exhibits an anomalous ("massindependent") oxygen isotopic composition. The isotopic composition of atmospheric nitrate is considered anomalous due to enrichment in ${ }^{17} \mathrm{O}$ relative to ${ }^{18} \mathrm{O}$ over the expected relationship $\left(\delta^{17} \mathrm{O} \approx 0.5 \times \delta^{18} \mathrm{O}\right)$ that results from purely massdependent fractionation processes (Matsuhisa et al., 1978). Isotope ratios are expressed in "delta notation",

$\delta^{x} \mathrm{O}=\frac{\left(\mathrm{O}^{x} / \mathrm{O}^{16}\right)_{\text {sample }}}{\left(\mathrm{O}^{x} / \mathrm{O}^{16}\right)_{\text {standard }}}-1$

where $x=17$ or 18 and the standard used for oxygen isotopic analysis is Standard Mean Ocean Water (SMOW). Generally, $\delta$ values are expressed in per mil $(\% o)$. The oxygen isotopic anomaly in nitrate, quantified here as $\Delta{ }^{17} \mathrm{O}=\delta^{17} \mathrm{O}-0.52 \times \delta^{18} \mathrm{O}$, results mainly from the transfer of an isotopic anomaly in atmospheric ozone during oxidation of $\mathrm{NO}$ and $\mathrm{NO}_{2}$ (Reactions R1 and R6 in Fig. 1).
Observations of the mean $\Delta^{17} \mathrm{O}$ value of tropospheric ozone $\left(\Delta^{17} \mathrm{O}\left(\mathrm{O}_{3}\right)\right)$ at different locations range from $25-35 \%$ o (Johnston and Thiemens, 1997; Krankowsky et al., 1995); the absolute variability is much larger (6-54\%o) (Morin et al., 2007). This large range in observed $\Delta{ }^{17} \mathrm{O}\left(\mathrm{O}_{3}\right)$ is unexpected based on the pressure and temperature dependence of the isotopic enrichment measured in laboratory studies (Morton et al., 1990). This discrepancy may be due to a bias (most likely low) in the observational data from this difficult measurement and/or uncertainties in the laboratory data. A photochemical equilibrium model constrained with laboratory data (Janssen et al., 1999; Mauersberger et al., 1999) calculates $\Delta{ }^{17} \mathrm{O}=35 \%$ o for surface ozone (Lyons, 2001) Michalski and Bhattacharya (2009) calculated $\Delta^{17} \mathrm{O}\left(\mathrm{O}_{3}\right)=33-37 \%$ o using a quadratic fit of data from Morton et al. (1990) assuming temperatures and pressures typical of mid-latitudes. Other oxidants $\left(\mathrm{OH}, \mathrm{RO}_{2}, \mathrm{HO}_{2}\right)$ involved in $\mathrm{NO}_{\mathrm{x}}$ cycling and nitrate formation have $\Delta^{17} \mathrm{O}$ values at or near zero (Dubey et al., 1997; Savarino and Thiemens, 1999a; Lyons, 2001; Savarino and Thiemens, 1999b). Observations of the $\Delta^{17} \mathrm{O}$ value of atmospheric nitrate $\left(\Delta^{17} \mathrm{O}\right.$ (nitrate) $)$ range from $\sim 10-40 \%$ o (Kaiser et al., 2007; McCabe et al., 2007; Michalski et al., 2003; Morin et al., 2007, 2008; Savarino et al., 2007; Brothers et al., 2008) highlighting the importance of ozone for reactive nitrogen chemistry in the atmosphere.

Reactive bromine $(\mathrm{BrO})$ can also play a role in both $\mathrm{NO}_{\mathrm{x}}$ cycling and nitrate formation in polar regions (Evans et al., 2003; Saiz-Lopez et al., 2008). BrO participates in $\mathrm{NO}_{\mathrm{x}} \mathrm{cy}-$ cling and nitrate formation through the following reactions:

$$
\begin{aligned}
& \mathrm{NO}+\mathrm{BrO} \rightarrow \mathrm{NO}_{2}+\mathrm{Br} \\
& \mathrm{NO}_{2}+\mathrm{BrO}+M \rightarrow \mathrm{BrONO}_{2}+M \\
& \mathrm{BrONO}_{2}+\mathrm{H}_{2} \mathrm{O}_{(\mathrm{aq})} \rightarrow \mathrm{HOBr}+\mathrm{HNO}_{3}
\end{aligned}
$$

$\mathrm{BrO}$ is expected to have large $\Delta^{17} \mathrm{O}$ values due to the involvement of $\mathrm{O}_{3}$ in $\mathrm{BrO}$ formation (Morin et al., 2007). The formation of nitrate through $\mathrm{BrO}$ oxidation and $\mathrm{BrONO}_{2}$ hydrolysis is thus expected to lead to large $\Delta^{17} \mathrm{O}$ (nitrate) values on the upper end of the range of observations. The global importance of reactive bromine in $\mathrm{NO}_{\mathrm{x}}$ cycling and nitrate formation remains to be quantified, but is thought to have significant regional impacts on both tropospheric $\mathrm{NO}_{\mathrm{x}}$ concentrations and ozone production (Yang et al., 2005).

Understanding the importance of different oxidants for $\mathrm{NO}_{\mathrm{x}}$ cycling and the pathways of nitrate formation is critical for understanding the budget of reactive nitrogen in the atmosphere. Here we present the first global chemical transport model of the oxygen isotopic composition of atmospheric nitrate. Comparison with available observations sheds light on previous assumptions used in box model studies regarding the isotopic composition of ozone and the isotopic transfer function during $\mathrm{NO}_{\mathrm{x}}$ oxidation reactions, and provides a means to test and validate the model's representation of reactive nitrogen chemistry. 


\section{Model description}

We utilize the GEOS-Chem global 3-D model of coupled aerosol-oxidant chemistry (Park et al., 2004) to simulate nitrate $\Delta^{17} \mathrm{O}$ and compare with observations. The model (version 8.01; see http://acmg.seas.harvard.edu/geos/geos versions.html) uses assimilated meteorological data from the NASA Goddard Earth Observing System (GEOS-4) including winds, convective mass fluxes, mixed layer depths, temperature, precipitation, and surface properties. Meteorological data have 6-hour temporal resolution (3-hour for surface variables and mixing depths). Meteorological fields have $1^{\circ} \times 1^{\circ}$ horizontal resolution with 48 sigma vertical levels (including seven below $1 \mathrm{~km}$ for a column based at sea-level). For input into GEOS-Chem, we degrade the horizontal resolution to $4^{\circ} \times 5^{\circ}$ and vertical resolution to 30 sigma levels. We conduct simulations for the year 2005 after a 12 month spin-up. The model was also run using May-June 2003 meteorological fields at $2^{\circ} \times 2.5^{\circ}$ horizontal resolution for comparison with the COCA cruise samples, and April-May 2007 meteorological fields at $4^{\circ} \times 5^{\circ}$ horizontal resolution for comparison with the Atlantic cruise samples (see Sect. 4). The time step for photochemical calculations in the model is $60 \mathrm{~min}$.

The tropospheric $\mathrm{O}_{3}-\mathrm{NO}_{\mathrm{x}}$-hydrocarbon simulation was first described by Bey et al. (2001) with updates by Fiore et al. (2002) and Martin et al. (2002). Emissions of $\mathrm{NO}_{\mathrm{x}}$ to-

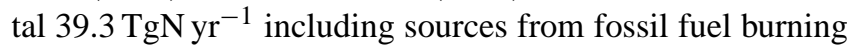
(including aircraft) $\left(25.2 \mathrm{TgN} \mathrm{yr}^{-1}\right)$, biofuel $\left(2.2 \mathrm{TgN} \mathrm{yr}^{-1}\right)$, biomass burning $\left(5.3 \mathrm{TgN} \mathrm{yr}^{-1}\right)$, lightning $\left(0.1 \mathrm{TgN} \mathrm{yr}^{-1}\right)$ and soil (including fertilizer) $\left(6.6 \mathrm{TgN} \mathrm{yr}^{-1}\right)$. Anthropogenic $\mathrm{NO}_{\mathrm{x}}$ emissions were taken from the Global Emission Inventory Activity (GEIA) (Benkovitz et al., 1996), scaled by country on the basis of energy statistics to the year 1995 as described by Bey et al. (2001). The monthly inventory of emissions from biomass burning are from the Global Fire Emissions Database (GFEDv2.1) for the year 2005 (Randerson et al., 2007; vanderWerf et al., 2006). Soil $\mathrm{NO}_{\mathrm{x}}$ emissions are computed using a modified version of the algorithm proposed by Yienger and Levy (1995) with the canopy reduction factors described by Wang et al. (1998). Emissions of $\mathrm{NO}_{\mathrm{x}}$ from lightning are linked to deep convection following the parameterization of Price and Rind (1992) with vertical profiles taken from Pickering et al. (1998). Stratospheric $\mathrm{NO}_{\mathrm{y}}\left(=\mathrm{NO}_{\mathrm{x}}+\mathrm{HNO}_{3}\right)$ concentrations are calculated using $\mathrm{NO}_{\mathrm{y}}$ production rates and its partitioning into $\mathrm{NO}_{\mathrm{x}}$ and $\mathrm{HNO}_{3}$ provided by a global 2-D stratospheric chemistry model (Schneider et al., 2000). The model represents transport of stratospheric $\mathrm{HNO}_{3}$ and $\mathrm{NO}_{\mathrm{x}}$ into the troposphere; however, there is no explicit representation of polar stratospheric cloud (PSC) sedimentation and resulting stratospheric denitrification.

The aerosol and oxidant chemistry are coupled through the formation of sulfate and nitrate, heterogeneous chemistry, and aerosol effects on photolysis rates. Optical prop- erties are calculated for each aerosol component as a function of local relative humidity as described by Martin et al. (2003). Reactions involving aerosols are described by Jacob (2000) with updates for $\mathrm{N}_{2} \mathrm{O}_{5}$ hydrolysis as described in Evans and Jacob (2005). Photolysis frequencies are computed using the Fast-J radiative transfer algorithm (Wild et al., 2000) which allows for Raleigh scattering as well as for Mie scattering by clouds and aerosols. Total inorganic nitrate is partitioned between the gas and particulate $(\leq 1 \mu \mathrm{m}$ diameter) phases for the $\mathrm{K}^{+}-\mathrm{Ca}^{2+}-\mathrm{Mg}^{2+}-\mathrm{NH}_{4}^{+}-\mathrm{Na}^{+}-\mathrm{SO}_{4}^{2-}$ $\mathrm{NO}_{3}^{-}-\mathrm{Cl}^{-}-\mathrm{H}_{2} \mathrm{O}$ aerosol system using the ISORROPIA II thermodynamic equilibrium model (Fountoukis and Nenes, 2007). We also consider kinetic uptake of $\mathrm{HNO}_{3}$ by coarsemode sea-salt aerosol ( $>1 \mu \mathrm{m}$ diameter) in competition with $\mathrm{SO}_{2}$ as described in Alexander et al. (2005). Wet deposition of aerosols is as described in Liu et al. (2001) and includes contributions from scavenging in convective updrafts, rainout and washout from convective anvils and largescale precipitation, and return to the atmosphere following re-evaporation. Dry deposition velocities for coarse-mode aerosols ( $>1 \mu \mathrm{m}$ diameter) are computed with the size dependent scheme of Zhang et al. (2001) integrated over each model size bin and accounting for hygroscopic growth as a function of relative humidity (Gerber, 1985). Dry deposition velocities for all other species are computed with a standard resistance-in-series scheme based on Wesely (1989) as described in Wang et al. (1998).

Calculation of $\Delta^{17} \mathrm{O}$ (nitrate) in the model applies a mass transfer approach similar to that first employed by Michalski et al. (2003). During the daytime, reactions involving the photochemical cycling of $\mathrm{NO}$ and $\mathrm{NO}_{2}$ (Reactions R1R4) will achieve photochemical steady-state at least 3 orders of magnitude faster than conversion of $\mathrm{NO}_{\mathrm{x}}$ to $\mathrm{HNO}_{3}$ (Reactions R5-R8) (Sander et al., 2000; DeMore et al., 1997). Ignoring for now the potential influence of reactive bromine chemistry, the $\Delta^{17} \mathrm{O}$ value of $\mathrm{NO}_{\mathrm{x}}\left(\Delta^{17} \mathrm{O}\left(\mathrm{NO}_{\mathrm{x}}\right)\right)$ is determined at photochemical steady-state by the relative production rates of $\mathrm{NO}_{2}$ via reaction of $\mathrm{NO}$ with $\mathrm{O}_{3}$ (Reactions $\mathrm{R} 1$ ), $\mathrm{HO}_{2}(\mathrm{R} 2)$ and $\mathrm{RO}_{2}(\mathrm{R} 3)$ and the $\Delta{ }^{17} \mathrm{O}$ value of $\mathrm{O}_{3}$,

$$
\begin{aligned}
& \Delta{ }^{17} \mathrm{O}\left(\mathrm{NO}_{\mathrm{x}}\right)=A \times \Delta{ }^{17} \mathrm{O}\left(\mathrm{O}_{3}^{*}\right) \\
& A=\frac{k_{\mathrm{R} 1}[\mathrm{NO}]\left[\mathrm{O}_{3}\right]}{k_{\mathrm{R} 1}[\mathrm{NO}]\left[\mathrm{O}_{3}\right]+k_{\mathrm{R} 2}[\mathrm{NO}]\left[\mathrm{HO}_{2}\right]+k_{\mathrm{R} 3}[\mathrm{NO}]\left[\mathrm{RO}_{2}\right]}
\end{aligned}
$$

where $k_{\mathrm{R} 1}, k_{\mathrm{R} 2}$, and $k_{\mathrm{R} 3}$ represent rate constants for Reactions (R1), (R2) and (R3) respectively. $\Delta^{17} \mathrm{O}\left(\mathrm{O}_{3}^{*}\right)$ represents the isotopic anomaly that is transferred from $\mathrm{O}_{3}$ to $\mathrm{NO}_{2}$ during oxidation of NO. $\Delta^{17} \mathrm{O}\left(\mathrm{O}_{3}^{*}\right)$ is not equal to $\Delta^{17} \mathrm{O}\left(\mathrm{O}_{3}\right)$ because of the isotopic asymmetry of ozone (Janssen, 2005; Bhattacharya et al., 2008; Michalski and Bhattacharya, 2009) combined with preferential transfer of the terminal oxygen atom from $\mathrm{O}_{3}$ to $\mathrm{NO}$ during oxidation (Savarino et al., 2008). Recent laboratory experiments suggest (Savarino et al., 2008):

$\Delta^{17} \mathrm{O}\left(\mathrm{O}_{3}^{*}\right)=1.18 \pm 0.07 \times \Delta^{17} \mathrm{O}\left(\mathrm{O}_{3}\right)+6.6 \pm 1.15$ 
where $\Delta^{17} \mathrm{O}\left(\mathrm{O}_{3}\right)$ is the bulk isotopic composition of ozone and $\Delta^{17} \mathrm{O}\left(\mathrm{O}_{3}^{*}\right)$ is used in Eqs. (2) and (4). The above calculation Eq. (2a) assumes that $\Delta^{17} \mathrm{O}\left(\mathrm{HO}_{2}\right)=0 \%$, in contrast to observations of $\Delta^{17} \mathrm{O}\left(\mathrm{H}_{2} \mathrm{O}_{2}\right)$ generally between 1$2 \%$ o $\left(\mathrm{H}_{2} \mathrm{O}_{2}\right.$ forms mainly through the self reaction of $\left.\mathrm{HO}_{2}\right)$ (Savarino and Thiemens, 1999b). However, the assumption that $\Delta^{17} \mathrm{O}\left(\mathrm{HO}_{2}\right)=0 \%$ versus $\Delta{ }^{17} \mathrm{O}\left(\mathrm{HO}_{2}\right)=2 \%$ o changes our calculated $\Delta{ }^{17} \mathrm{O}$ (nitrate) by less than $1 \%$ over the global range of calculated $A$ values (Fig. 3 and Sect. 4.2) and simplifies the calculations. The assumption that $\Delta{ }^{17} \mathrm{O}\left(\mathrm{HO}_{2}\right)=0 \%$ o is also consistent with other studies (Michalski et al., 2003; Morin et al., 2008; Kunasek et al., 2008). $\mathrm{NO}_{\mathrm{x}}$ will achieve isotopic equilibrium locally with $\mathrm{O}_{3}, \mathrm{HO}_{2}$, and $\mathrm{RO}_{2}$ during the daytime prior to conversion to nitrate. For the daytime (Reaction R5), the local $A_{\text {day }}$ value is calculated in the model based on the relative $\mathrm{NO}_{2}$ production rates (Reactions R1R3) between 10:00-14:00 hours local time. For the nighttime (Reactions R6, R6 and R6, R8), calculation of the local $A$ value is more complicated because photochemical steadystate does not exist at night. Since peroxy radical concentrations (whose production rates are dependent upon UV radiation) will drop off before $\mathrm{NO}_{\mathrm{x}}$ cycling (which occurs at visible wavelengths) ceases, $\mathrm{NO}_{\mathrm{x}}$ will continue achieve isotopic equilibrium in the late afternoon resulting in $A$ values near unity. Thus, for the nighttime (Reactions R6, R7 and R6, R8), the local $A_{\text {night }}$ value is calculated based on the relative $\mathrm{NO}_{2}$ production rates between midnight to $2 \mathrm{am}$ local time. This assumes that the relative importance of $\mathrm{O}_{3}$ and peroxy radicals in the oxidation of $\mathrm{NO}$ to $\mathrm{NO}_{2}$ at night is similar to that during dusk when $\mathrm{NO}_{\mathrm{x}}$ photochemical steady-state exists. This assumption may result in an overestimate of $\Delta^{17} \mathrm{O}$ (nitrate) $)_{\mathrm{R} 6, \mathrm{R} 7}$ and $\Delta^{17} \mathrm{O}$ (nitrate) $)_{\mathrm{R} 6, \mathrm{R} 8}$ due to a broadening of the peroxy radical diurnal cycle from photolysis of species other than ozone (e.g. $\mathrm{HCHO}, \mathrm{HONO}, \mathrm{H}_{2} \mathrm{O}_{2}$, $\mathrm{CH}_{3} \mathrm{O}_{2} \mathrm{H}$ ) (Fleming et al., 2006; Carpenter et al., 1997), but is likely to be small on the global scale.

Nitrate in the model is transported as four separate tracers depending on its production pathway (Reactions R5-R8 in Fig. 1 plus stratospheric nitrate). Each nitrate tracer is assigned a $\Delta{ }^{17} \mathrm{O}$ value according to its involvement with $\mathrm{O}_{3}$ during formation, similar to that proposed by (Michalski et al., 2003):

$$
\begin{aligned}
& \Delta^{17} \mathrm{O}(\text { nitrate })_{\mathrm{R} 5}=2 / 3 A_{\text {day }} \Delta^{17} \mathrm{O}\left(\mathrm{O}_{3}^{*}\right) \\
& \Delta^{17} \mathrm{O}(\text { nitrate })_{\mathrm{R} 6, \mathrm{R} 7}=1 / 3 \Delta \Delta^{17} \mathrm{O}\left(\mathrm{O}_{3}^{*}\right)\left(2 \times A_{\text {night }}+1\right) \\
& \Delta^{17} \mathrm{O}(\text { nitrate })_{\mathrm{R} 6, \mathrm{R} 8}=1 / 6 \Delta^{17} \mathrm{O}\left(\mathrm{O}_{3}^{*}\right)\left(4 \times A_{\text {night }}+1\right) \\
& \Delta^{17} \mathrm{O}(\text { nitrate })_{\text {strat }}=5 / 6 \Delta^{17}\left(\mathrm{O}_{3}^{*}\right)_{\text {strat }}
\end{aligned}
$$

We assume $\mathrm{O}_{3}$ will dominate $\mathrm{NO}_{\mathrm{x}}$ cycling in the stratosphere leading to $A=1$. We use a factor of $5 / 6$ to calculate the $\Delta^{17} \mathrm{O}$ value of stratospheric nitrate $\left.\left(\Delta^{17} \mathrm{O} \text { (nitrate }\right)_{\text {strat }}\right)$ to be consistent with other studies (McCabe et al., 2007; Savarino et al., 2007) that assume stratospheric nitrate forms via $\mathrm{N}_{2} \mathrm{O}_{5}$ hydrolysis. This neglects nitrate formation via $\mathrm{ClONO}_{2}$ decomposition and possible non-zero values of $\Delta^{17} \mathrm{O}\left(\mathrm{H}_{2} \mathrm{O}\right)_{\text {strat }}$ (Franz et al., 2005; Zahn et al., 2006), leading to a possible underestimate of $\Delta^{17} \mathrm{O}$ (nitrate) strat $_{\text {. However, our results }}$ are insensitive to this assumption as stratospheric nitrate is a negligible source of nitrate in the model (Sect. 4.2).

$\Delta{ }^{17} \mathrm{O}$ (nitrate) is calculated according to the local importance of $\mathrm{O}_{3}$ in $\mathrm{NO}_{\mathrm{x}}$ cycling $(A)$ and the relative abundance of each nitrate tracer (from transport and local production) according to the following,

$$
\begin{aligned}
& \Delta^{17} \mathrm{O}(\text { nitrate })=f_{\mathrm{R} 5} \Delta^{17} \mathrm{O}(\text { nitrate })_{\mathrm{R} 5}+ \\
& f_{\mathrm{R} 6, \mathrm{R} 7} \Delta^{17} \mathrm{O}(\text { nitrate })_{\mathrm{R} 6, \mathrm{R} 7}+ \\
& f_{\mathrm{R} 6, \mathrm{R} 8} \Delta^{17} \mathrm{O}(\text { nitrate })_{\mathrm{R} 6, \mathrm{R} 8}+f_{\text {strat }} \Delta^{17} \mathrm{O}(\text { nitrate })_{\text {strat }}
\end{aligned}
$$

$$
\begin{aligned}
& f_{\mathrm{R} 5}=\frac{[\text { nitrate }]_{\mathrm{R} 5}}{[\text { nitrate }]_{\mathrm{total}}}, \\
& f_{\mathrm{R} 6, \mathrm{R} 7}=\frac{[\text { nitrate }]_{\mathrm{R} 6, \mathrm{R} 7}}{[\text { nitrate }]_{\mathrm{total}}}, \\
& f_{\mathrm{R} 6, \mathrm{R} 8}=\frac{[\text { nitrate }]_{\mathrm{R} 6, \mathrm{R} 8}}{[\text { nitrate }]_{\text {total }}}, \\
& f_{\text {strat }}=\frac{[\text { nitrate }]_{\text {strat }}}{[\text { nitrate }]_{\text {total }}} \\
& f_{\mathrm{R} 5}+f_{\mathrm{R} 6, \mathrm{R} 7}+f_{\mathrm{R} 6, \mathrm{R} 8}+f_{\text {strat }}=1
\end{aligned}
$$

where, for example, [nitrate $]_{\mathrm{R} 5}$ is the concentration of nitrate formed through $\mathrm{NO}_{2}+\mathrm{OH}$ (Reaction R5) and [nitrate] total is the total concentration of inorganic nitrate. This formulation captures the effect of transport on $\Delta^{17} \mathrm{O}$ (nitrate) with respect to oxidation of $\mathrm{NO}_{2}$ to $\mathrm{HNO}_{3}$. It does not capture the effect of transport on $\Delta^{17} \mathrm{O}\left(\mathrm{NO}_{\mathrm{x}}\right)$ due to the use of local $A$ values in calculating $\Delta^{17} \mathrm{O}$ (nitrate). This greatly simplifies the calculations but introduces some error in calculated values of $\Delta{ }^{17} \mathrm{O}$ (nitrate). This error will be most significant in remote regions with no local sources of $\mathrm{NO}_{\mathrm{x}}$ (e.g. polar winter) - the magnitude of this error $(4-5 \%$ ) is explored in more detail in Sect. 4.3.

We perform sensitivity studies to cover the range of observed tropospheric $\Delta^{17} \mathrm{O}\left(\mathrm{O}_{3}\right)$ values $(25-35 \%$ ). We assume stratospheric $\Delta^{17} \mathrm{O}\left(\mathrm{O}_{3}\right)=40 \%$ in all simulations, a value towards the upper end of observations (10.4-45.7\%o) (Mauersberger et al., 2001) and consistent with model studies (Liang et al., 2006). We note that calculations of $\Delta^{17} \mathrm{O}$ (nitrate) formed within the troposphere use tropospheric values for $\Delta^{17} \mathrm{O}\left(\mathrm{O}_{3}\right)$. We do not distinguish between tropospheric and stratospheric-derived $\Delta^{17} \mathrm{O}\left(\mathrm{O}_{3}\right)$ within the troposphere. Globally, production within the troposphere dominates tropospheric ozone (Prather and Ehhalt, 2001); however, this distinction may be important locally, particularly at high altitudes in the mid- to high-latitudes, and its importance will 
vary seasonally. For example, (Terao et al., 2008) estimated that stratospheric-derived ozone peaked at $40 \%$ (30\%) of total ozone in spring in high (mid) latitudes at $500 \mathrm{hPa}$; however, the contribution of stratospheric ozone at the surface is generally small (Fiore et al., 2003). The magnitude of the error introduced upon our tropospheric $\Delta^{17} \mathrm{O}$ (nitrate) calculations will depend upon the difference between the value of $\Delta^{17} \mathrm{O}\left(\mathrm{O}_{3}\right)$ produced in the troposphere and stratosphere, as well as the influence of stratospheric-derived ozone at any particular location. Since nitrate production is dominated in the boundary layer, we expect this error in general to be small at the surface at low altitudes where most of the observations of $\Delta^{17} \mathrm{O}$ (nitrate) are located, but could be of seasonal importance in the mid-to high-latitudes.

Previous box-model studies have assumed either an equal likelihood of all three $\mathrm{O}$-atoms of $\mathrm{O}_{3}$ (Michalski et al., 2003; Kunasek et al., 2008) or favored oxidation by the terminal Oatom of $\mathrm{O}_{3}$ (Morin et al., 2008) during oxidation of $\mathrm{NO}$ and $\mathrm{NO}_{2}$. We perform additional sensitivity studies to account for differing assumptions regarding the transfer mechanism of the isotopic anomaly from $\mathrm{O}_{3}$ to $\mathrm{NO}_{2}$ and $\mathrm{NO}_{3}$ upon oxidation (Reactions R1 and R6). Whether or not the terminal O-atom of ozone is favored as the reacting atom influences the resulting isotopic composition of nitrate because the asymmetric isotopologues of ozone are enriched in heavy oxygen isotopes with respect to bulk ozone (e.g. ${ }^{18} \mathrm{O}^{16} \mathrm{O}^{16} \mathrm{O}$ vs. ${ }^{16} \mathrm{O}^{18} \mathrm{O}^{16} \mathrm{O}$ ) (Janssen, 2005; Bhattacharya et al., 2008; Michalski and Bhattacharya, 2009).

\section{Observations}

The observations include monthly average $\Delta^{17} \mathrm{O}$ (nitrate) of aerosol samples collected from Alert, Canada $\left(82^{\circ} \mathrm{N}\right.$, $62^{\circ} \mathrm{W}$ ) (Morin et al., 2008), La Jolla, California $\left(33^{\circ} \mathrm{N}\right.$, $117^{\circ} \mathrm{W}$ ) (Michalski et al., 2003), Dumont D'Urville, Antarctica $\left(66^{\circ} \mathrm{S}, 140^{\circ} \mathrm{E}\right)$ (Savarino et al., 2007), the South Pole (McCabe et al., 2007), and daily averaged aerosol samples from the COCA (Carbono Orgánico en la corriente CAnarias) cruise (Dachs et al., 2005; Duarte et al., 2006) in the subtropical north Atlantic in May-June 2003 (21-28 N, 14$26^{\circ} \mathrm{W}$ ) (Alexander et al., unpublished data) and from an Atlantic ocean cruise in April-May $2007\left(28^{\circ} \mathrm{S}-52^{\circ} \mathrm{N}, 21^{\circ} \mathrm{W}-\right.$ $12^{\circ} \mathrm{E}$ ) (Morin et al., 2009). Event-based rainwater samples are averaged over each month of collection from Princeton, New Jersey $\left(40^{\circ} \mathrm{N}, 75^{\circ} \mathrm{W}\right)$ (Kaiser et al., 2007) and Bermuda $\left(32^{\circ} \mathrm{N}, 65^{\circ} \mathrm{W}\right)$ (Hastings et al., 2003) to compare with monthly-resolved model output. Fog-water samples collected in the Podocarpus National Forest, Ecuador $\left(4^{\circ} \mathrm{S}\right.$, $79^{\circ} \mathrm{W}$ ) are averaged over the course of three years (20042006) (Brothers et al., 2008). The observations also include seasonally-resolved snowpit samples from Summit, Greenland $\left(73^{\circ} \mathrm{N}, 39^{\circ} \mathrm{W}\right)$ (Kunasek et al., 2008), and annualaverage nitrate collected from passive deposition collectors in the Atacama desert (Yungay), Chile $\left(24^{\circ} \mathrm{S}, 70^{\circ} \mathrm{W}\right)(\mathrm{Ew}-$ ing et al., 2007).

Observations of $\Delta^{17} \mathrm{O}$ (nitrate) were made using two types of analysis: the "silver salt pyrolysis" method (Michalski et al., 2002) (observations from La Jolla, South Pole, Summit, Chile, Ecuador and COCA) and the "denitrifier" method (Kaiser et al., 2007) (observations from Alert, Dumont D'Urville, Princeton, Bermuda, and the Atlantic cruise). The silver salt pyrolysis method relies on isolation of dissolved, inorganic nitrate $\left(\mathrm{NO}_{3}^{-}\right)$prior to analysis. Nitrate anion separation ensures that only inorganic nitrate is measured, assuming that soluble organic nitrate does not dissociate in water. Observations of $\mathrm{C}_{1}-\mathrm{C}_{5}$ alkyl nitrates in wet deposition (rain, snow, frost) (Hauff et al., 1998) suggest that they do not readily dissociate. The denitrifier method does not require isolation of $\mathrm{NO}_{3}^{-}$and uses denitrifying bacteria (Pseudomonas aureofaciens) to convert nitrate (and nitrite) into $\mathrm{N}_{2} \mathrm{O}$, which is then quantitatively thermally decomposed into $\mathrm{O}_{2}$ and $\mathrm{N}_{2}$. It is generally assumed that the denitrifier method selectively measures inorganic nitrate; however, this has yet to be specifically demonstrated. Hawari et al. (2000) showed that biological degradation of RDX (hexahydro-1,3,5-trinitro-1,3,5triazine) produced $\mathrm{N}_{2} \mathrm{O}$ as a byproduct, suggesting that certain types of microorganisms can convert soluble organic nitrates into $\mathrm{N}_{2} \mathrm{O}$. It is not known whether or not Pseudomonas aureofaciens will do the same. As will be shown, whether or not we include organic nitrates in our isotope calculations is significant for calculated $\Delta^{17} \mathrm{O}$ (nitrate) in regions where organic nitrates are abundant.

\section{Results and discussion}

\subsection{Model comparison with observations}

Figure 2 compares $\Delta^{17} \mathrm{O}$ (nitrate) model results with observations. The model is sampled at the same time resolution as the observations (daily, monthly and annual mean). Each panel represents a different assumption in the model regarding the isotopic composition of ozone and the isotopic transfer mechanism. On average, assuming $\Delta{ }^{17} \mathrm{O}\left(\mathrm{O}_{3}\right)=35 \%$ o with a statistical transfer (Fig. 2a) underestimates the $\Delta^{17} \mathrm{O}$ (nitrate) observations by $20 \pm 10 \%$ $(1 \sigma)$. Assuming $\Delta^{17} \mathrm{O}\left(\mathrm{O}_{3}\right)=25 \%$ with a statistical transfer (Fig. 2b) underestimates the $\Delta^{17} \mathrm{O}$ (nitrate) observations by $50 \pm 10 \%(1 \sigma)$. Assuming $\Delta{ }^{17} \mathrm{O}\left(\mathrm{O}_{3}\right)=35 \%$ with the Savarino et al. (2008) isotopic transfer applied to $\mathrm{NO}+\mathrm{O}_{3}$ and $\mathrm{NO}_{2}+\mathrm{O}_{3}$ (Fig. 2c) agrees with the $\Delta^{17} \mathrm{O}$ (nitrate) observations within $\pm 10 \%(1 \sigma)$. Assuming $\Delta{ }^{17} \mathrm{O}\left(\mathrm{O}_{3}\right)=25 \%$ o with the Savarino et al. (2008) isotopic transfer applied to $\mathrm{NO}+\mathrm{O}_{3}$ and $\mathrm{NO}_{2}+\mathrm{O}_{3}$ (Fig. 2d) underestimates the $\Delta^{17} \mathrm{O}$ (nitrate) observations by $20 \pm 10 \%(1 \sigma)$.

Based on Fig. 2, we focus our analysis using the model simulation that assumes $\Delta{ }^{17} \mathrm{O}\left(\mathrm{O}_{3}\right)=35 \%$ o with the Savarino et al. (2008) $\Delta^{17} \mathrm{O}$ transfer applied to both the $\mathrm{NO}+\mathrm{O}_{3}$ and 


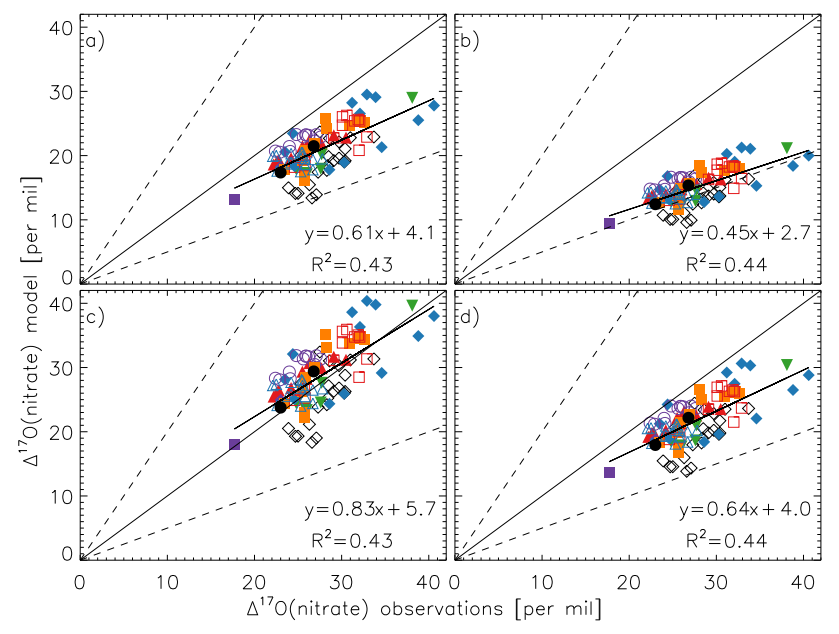

Fig. 2. Scatter plot of monthly-mean model calculations at the surface versus observations. Observations include: Bermuda (black circles), La Jolla (red triangles), South Pole (green triangles), DDU (blue diamonds), Chile (purple diamond), Princeton (purple open circles), Summit (orange squares), Alert (red open squares), Ecuador (purple square), COCA (blue open triangles), and an Atlantic cruise (black open squares). Each panel uses different assumptions regarding the bulk isotopic composition of ozone and the isotopic transfer mechanism during ozone oxidation: (a) $\Delta^{17} \mathrm{O}\left(\mathrm{O}_{3}\right)=35 \%$ and statistical $\Delta^{17} \mathrm{O}$ transfer, (b) $\Delta{ }^{17} \mathrm{O}\left(\mathrm{O}_{3}\right)=25 \%$ and statistical $\Delta{ }^{17} \mathrm{O}$ transfer (c) $\Delta{ }^{17} \mathrm{O}\left(\mathrm{O}_{3}\right)=35 \%$ o and Savarino et al. (2008) transfer applied to $\mathrm{NO}+\mathrm{O}_{3}$ and $\mathrm{NO}_{2}+\mathrm{O}_{3}$, (d) $\Delta^{17} \mathrm{O}\left(\mathrm{O}_{3}\right)=25 \%$ and Savarino et al. (2008) transfer applied to $\mathrm{NO}+\mathrm{O}_{3}$ and $\mathrm{NO}_{2}+\mathrm{O}_{3}$. The linear least-squares regression (thick), $y=x$ (solid), $y=2 x$ and $y=0.5 x$ (dashed) lines are shown. Inset is the regression equation and $R^{2}$ values.

$\mathrm{NO}_{2}+\mathrm{O}_{3}$ reactions. Although the comparison in Fig. 2 suggests that $\Delta^{17} \mathrm{O}\left(\mathrm{O}_{3}\right)=35 \%$ is the appropriate value to use in calculations of $\Delta^{17} \mathrm{O}$ (nitrate), it is no substitute for direct observations of $\Delta^{17} \mathrm{O}\left(\mathrm{O}_{3}\right)$, as model biases will impact our results. Model errors in transport may impact for example the vertical distribution of $\mathrm{NO}_{\mathrm{x}}$, which will in turn influence $\Delta^{17} \mathrm{O}$ (nitrate) due to changing $A$ values (generally decreasing with height) or changes in the importance of different nitrate formation pathways with altitude. Global biases in oxidant $\left(\mathrm{O}_{3}, \mathrm{NO}_{3}, \mathrm{OH}, \mathrm{RO}_{2}, \mathrm{HO}_{2}\right)$ concentrations or the formation rate of nitrate for specific pathways (e.g. $\mathrm{N}_{2} \mathrm{O}_{5}$ hydrolysis) will also impact the isotopic calculations. For example, if the true $\Delta^{17} \mathrm{O}\left(\mathrm{O}_{3}\right)=25 \%$, then our finding that $\Delta^{17} \mathrm{O}\left(\mathrm{O}_{3}\right)=35 \%$ provides the best agreement between observed and modeled $\Delta{ }^{17} \mathrm{O}$ (nitrate) may indicate that the model globally and systematically underestimates (overestimates) $\mathrm{O}_{3}$ and/or $\mathrm{NO}_{3}(\mathrm{OH}$ and/or peroxy radical) concentrations. The resulting magnitude of the bias in $\Delta^{17} \mathrm{O}$ (nitrate) will be dependent upon the magnitude of the bias in $\mathrm{O}_{3}, \mathrm{NO}_{3}, \mathrm{OH}$, or peroxy radical concentrations. Our calculated global mean $\mathrm{OH}$ concentration $\left(10.7 \times 10^{5}\right.$ molecules $\left.\mathrm{cm}^{-3}\right)$ compares well with (Wang et al., 2008) $\left(10.6 \times 10^{5}\right.$ molecules $\left.\mathrm{cm}^{-3}\right)$ who optimized the global abundance of $\mathrm{OH}$ by interpreting observations of methyl chloroform using an inverse technique and the GEOS-Chem model. This suggests no global, systematic bias in $\mathrm{OH}$. Calculated $\mathrm{O}_{3}$ concentrations in the GEOSChem model has been extensively evaluated against observations (Hudman et al., 2009; Zhang et al., 2008; Terao et al., 2008; Wu et al., 2007; Wang et al., 2009), suggesting no systematic global bias. Peroxy radical concentrations would have to be overestimated globally by a factor of $\sim 3$ to account for a $10 \%$ difference in $\Delta^{17} \mathrm{O}\left(\mathrm{NO}_{\mathrm{x}}\right)$. Although we may expect significant regional biases in these radical concentrations, a systematic global bias seems unlikely for species (or nitrate formation pathways) with a high degree of spatial variability.

We note that Michalski et al. (2003) and Kunasek et al. (2008) achieved good agreement with observations of $\Delta^{17} \mathrm{O}$ (nitrate) using a box models that assumed $\Delta{ }^{17} \mathrm{O}\left(\mathrm{O}_{3}\right)=35 \%$ o with the statistical transfer function. In their analysis of observed $\Delta^{17} \mathrm{O}$ (nitrate) in La Jolla, CA, Michalski et al. (2003) estimated a much larger fraction of nitrate formed via $\mathrm{N}_{2} \mathrm{O}_{5}$ hydrolysis $(30-90 \%)$ than we do (5-50\%), revealing the sensitivity of $\Delta^{17} \mathrm{O}$ (nitrate) to the fractional contribution of $\mathrm{N}_{2} \mathrm{O}_{5}$ hyrolysis to total nitrate formation. We expect that Michalski et al. (2003) significantly overestimated the contribution of $\mathrm{N}_{2} \mathrm{O}_{5}$ hydrolysis in their model due to the use of a reaction rate constant that did not account for variability of factors such as aerosol surface area, chemical composition, humidity and temperature. Also, it is generally thought that models overestimate the importance of nitrate formation via $\mathrm{N}_{2} \mathrm{O}_{5}$ hydrolysis through overestimates of the reaction probability (Davis et al., 2008; McNeill et al., 2006; Brown et al., 2009). Kunasek et al. (2008) also obtained good agreement with snowpit observations of $\Delta{ }^{17} \mathrm{O}$ (nitrate) in Summit, Greenland with a box model that assumed $\Delta{ }^{17} \mathrm{O}\left(\mathrm{O}_{3}\right)=35 \%$ with the statistical isotopic transfer function. Their box model used boundary conditions from the same global model used here (GEOS-Chem), but inherently did not account for transport of nitrate formed at lower latitudes (with lower values of $\Delta^{17} \mathrm{O}$ (nitrate)). This demonstrates the importance of accounting for transport of nitrate from different regions with potentially different values of $\Delta{ }^{17} \mathrm{O}$ (nitrate), particularly for remote polar locations far from major sources of $\mathrm{NO}_{\mathrm{x}}$.

\subsection{Global variability of tropospheric nitrate formation pathways and $\Delta^{17} \mathbf{O}$ (nitrate)}

Figure 3 shows global plots of modeled June-July-August and December-January-February mean $\Delta^{17} \mathrm{O}$ (nitrate) in the lowest model layer $(0-200 \mathrm{~m}$ above the surface). $\Delta^{17} \mathrm{O}$ (nitrate) ranges from $7-41 \%$, with $A_{\text {day }}$ and $A_{\text {night }}$ generally ranging from $0.2-1.0$ and $0.9-1.0$, respectively. The spatial variability of $\Delta^{17} \mathrm{O}$ (nitrate) is largely determined by the importance of $\mathrm{O}_{3}$ in $\mathrm{NO}_{\mathrm{x}}$ cycling $(A)$ due to the fact that 
$\Delta^{17} O($ nitrate) $(J J A)$

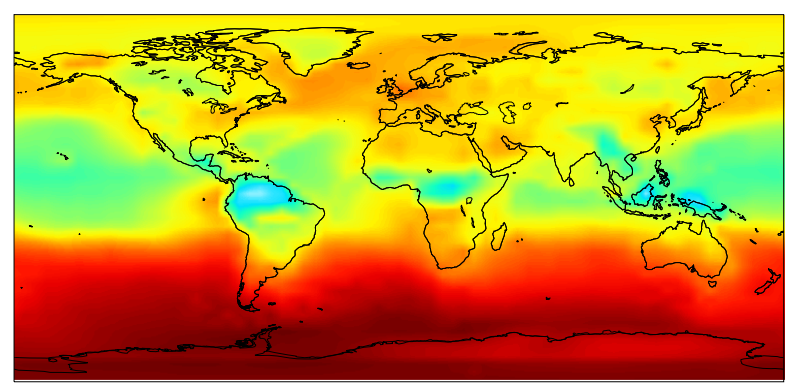

$\Delta^{17} O($ nitrate $)(D \cdot F)$

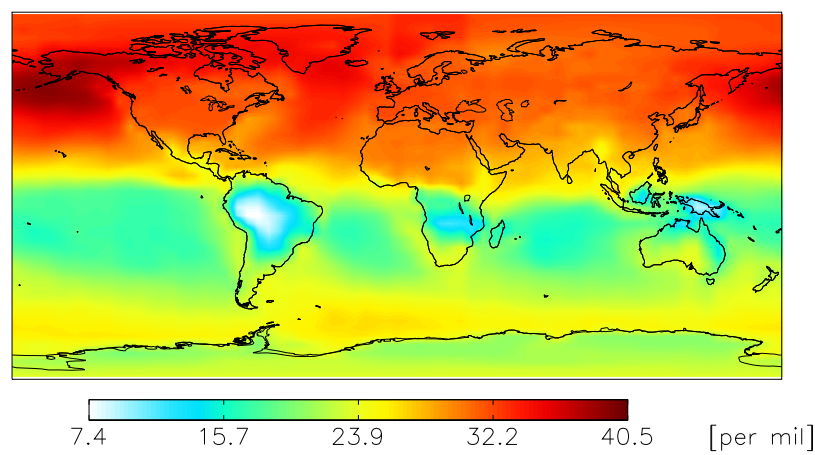

Fig. 3. June-July-August (top) and December-January-February (bottom) average nitrate $\Delta^{17} \mathrm{O}(\%)$ values $0-200 \mathrm{~m}$ above the surface.

the isotopic composition of two-thirds of the oxygen atoms of nitrate is determined during $\mathrm{NO}_{\mathrm{x}}$ cycling. The oxidation of $\mathrm{NO}_{\mathrm{x}}$ to nitrate plays a secondary but significant role in determining the final $\Delta{ }^{17} \mathrm{O}$ (nitrate) value.

Figure 4 shows the fractional importance of each nitrate production pathway to annual mean nitrate concentrations in the lowest model layer $(0-200 \mathrm{~m}$ above the surface). Nitrate production via $\mathrm{NO}_{2}+\mathrm{OH}$ (Reaction R5) dominates (up to $87 \%$ ) in the tropics where $\mathrm{OH}$ concentrations are highest. Nitrate production via $\mathrm{N}_{2} \mathrm{O}_{5}$ hydrolysis (Reaction $\mathrm{R} 8$ ) dominates (up to $74 \%$ ) at high northern latitudes over the continents and the Arctic, consistent with observations and modeling by Tie et al. (2003) and Stroud et al. (2003). Nitrate production via reaction of $\mathrm{NO}_{3}$ with (primarily) DMS (Reaction R7) is most important (up to 46\%) in the high latitudes in the marine boundary layer. The stratospheric source of nitrate is negligible (annual average maximum of $2 \%$ in Antarctica). The annual-mean fractional contribution to the tropospheric inorganic nitrate burden for nitrate formed via $\mathrm{NO}_{2}+\mathrm{OH}$ (Reaction R5), $\mathrm{N}_{2} \mathrm{O}_{5}$ hydrolysis (Reactions R6, $\mathrm{R} 8$ ), and $\mathrm{NO}_{3}+\mathrm{DMS} / \mathrm{HC}$ (Reactions $\mathrm{R} 6, \mathrm{R} 7$ ) is $76 \%, 18 \%$, and $4 \%$, respectively. The remaining inorganic nitrate burden $(2 \%)$ is from the stratosphere.

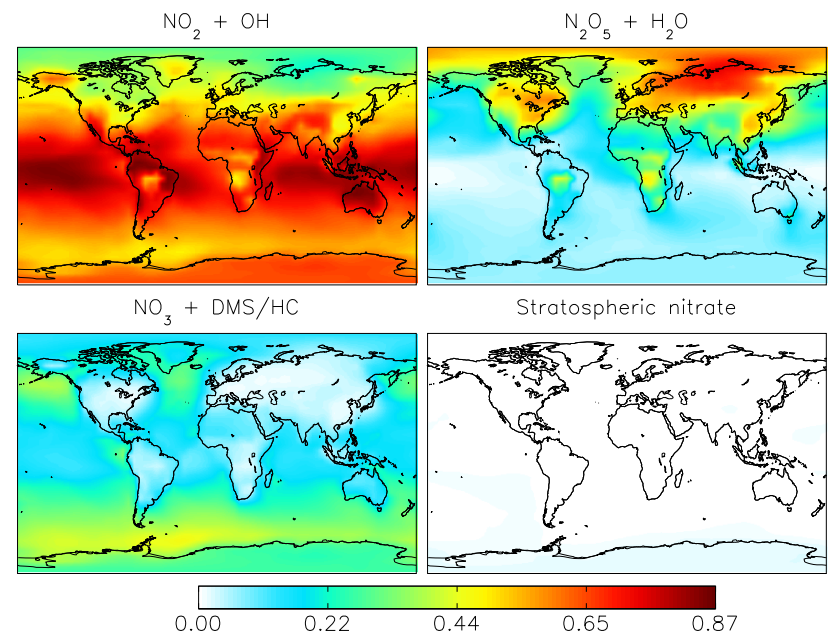

Fig. 4. Annual-mean fractional importance of each nitrate production pathway leading to total inorganic nitrate at the surface in the model: $\mathrm{NO}_{2}+\mathrm{OH}$ (top left), $\mathrm{N}_{2} \mathrm{O}_{5}$ hydrolysis (top right), $\mathrm{NO}_{3}+\mathrm{DMS} / \mathrm{HC}$ (bottom left), and stratospheric nitrate (bottom right).

The largest values of $\Delta^{17} \mathrm{O}$ (nitrate) occur in the winter hemisphere high latitudes (Fig. 3) due to the increased importance of $\mathrm{O}_{3}$ in $\mathrm{NO}_{\mathrm{x}}$ cycling (Reaction R1) and nitrate formation (Reaction R6). McCabe et al. (2007) estimated an annual average contribution of $25 \%$ stratospheric nitrate at the South Pole based on measurements of aerosol $\Delta^{17} \mathrm{O}$ (nitrate). In their analysis, McCabe et al. (2007) assumed tropospheric $\Delta{ }^{17} \mathrm{O}\left(\mathrm{O}_{3}\right)=27.1 \pm 4.8 \%$ and an isotopic transfer mechanism that results in a depletion of $\Delta^{17} \mathrm{O}$ (nitrate) relative to $\Delta^{17} \mathrm{O}\left(\mathrm{O}_{3}\right)$ (so that $\Delta^{17} \mathrm{O}\left(\mathrm{O}_{3}^{*}\right)<\Delta^{17} \mathrm{O}\left(\mathrm{O}_{3}\right)$ ). In contrast, our calculated $\Delta^{17} \mathrm{O}$ (nitrate) at the South Pole is similar in magnitude and seasonality to the observations (McCabe et al., 2007), with stratospheric nitrate contributing $<5 \%$ in winter. It is important to note here that we are likely underestimating the stratospheric source in polar-regions due to the lack of an explicit stratospheric denitrification mechanism from the sedimentation of PSCs in the model. Stratospheric nitrate is thought to be an important (but unquantified) source of nitrate to Antarctica (Legrand and Kirchner, 1990; McMorrow et al., 2004; Mulvaney and Wolff, 1993; Wagenbach et al., 1998; Weller et al., 2002; Savarino et al., 2007). Indeed, the lack of a stratospheric denitrification mechanism in the model may explain the model's inability to capture the seasonality of the observations at DDU, Antarctica (Savarino et al., 2007) (see Fig. 5).

The smallest values of $\Delta^{17} \mathrm{O}$ (nitrate) occur in the summer hemisphere and in the tropics due to the increased importance of peroxy radicals (Reactions $\mathrm{R} 2$ and $\mathrm{R} 3$ ) in $\mathrm{NO}_{\mathrm{x}}$ cycling and nitrate production via $\mathrm{NO}_{2}+\mathrm{OH}$ (Reaction R5), with annual mean values as low as $7 \%$ in tropical forested regions. Observations (using the silver salt pyrolysis method) 


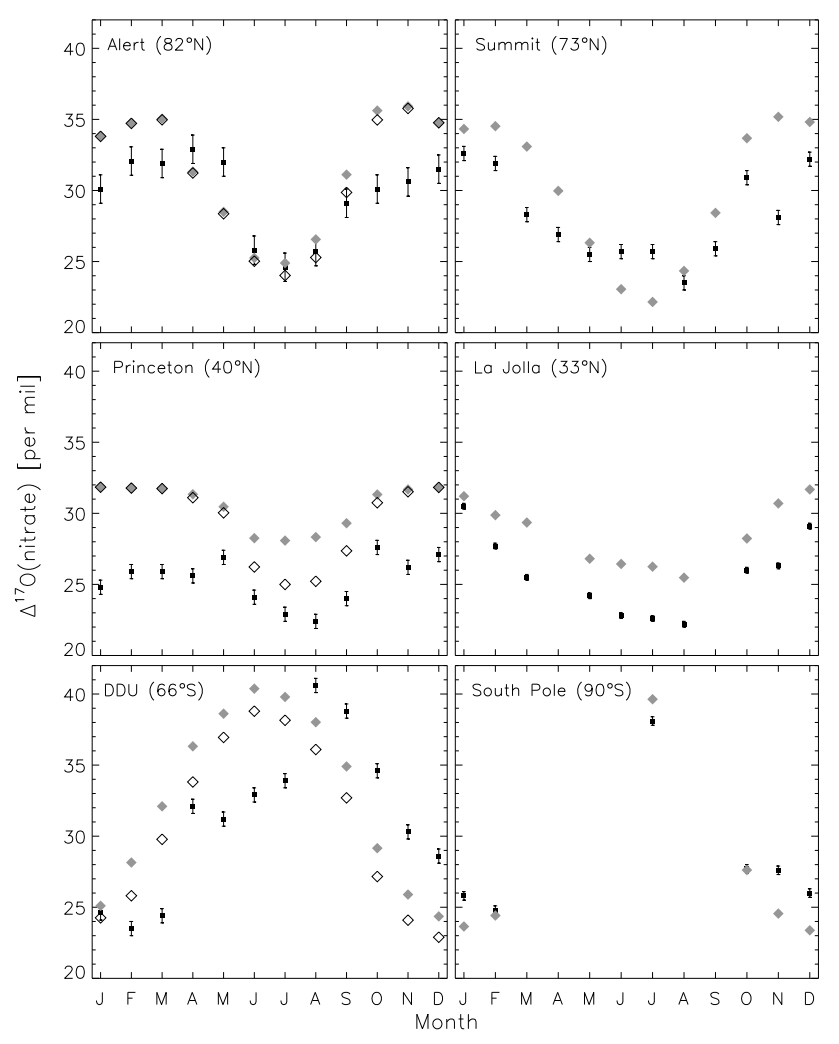

Fig. 5. Monthly mean nitrate $\Delta^{17} \mathrm{O}(\%$ o) observations (black squares with $\pm 1 \sigma$ error bars) and model calculations at the surface (gray diamonds) at Summit, Greenland (Kunasek et al., 2008), Alert, Canada (Morin et al., 2008), Princeton, NJ (Kaiser et al., 2007), La Jolla, CA (Michalski et al., 2003), Dumont d'Urville, Antarctica (Savarino et al., 2007), and the South Pole (McCabe et al., 2007). A sensitivity simulation including organic nitrates in the $\Delta^{17} \mathrm{O}$ (nitrate) calculation (open diamonds) is also shown. The observations utilize the denitrifier method (Kaiser et al., 2007) (left panels) and the silver salt pyrolysis method (Michalski et al., 2002) (right panels).

of $\Delta^{17} \mathrm{O}$ (nitrate) in fog-water collected in the Podocarpus National Forest, Ecuador $\left(4^{\circ} \mathrm{S}, 79^{\circ} \mathrm{W}\right)$ show a range of annual average values over three years (2004-2006) of 13$22 \%$ o (Brothers et al., 2008). Our monthly-mean model results vary between $17-21 \%$ with an annual-average of $18.0 \%$ at this location.

\subsection{Model discrepancies}

Figure 5 compares monthly-mean $\Delta^{17} \mathrm{O}$ (nitrate) model calculations with observations available over the course of a full year (Alert, Summit, Princeton, La Jolla, DDU, and the South Pole). The model reproduces the seasonality of the $\Delta{ }^{17} \mathrm{O}$ (nitrate) observations. The model shows good agreement (generally within 5\%o) with the observations in lowto mid-latitudes (La Jolla, Bermuda, COCA, Atlantic cruise, Chile and Ecuador; Fig. 2), though additional observations in low-latitude forested regions are necessary to validate model predictions of $\Delta^{17} \mathrm{O}$ (nitrate) less than $20 \%$ o. In general, the model tends to underestimate the observations during spring and summer in polar-regions by $0-5 \%$, and overestimate the observations in the northern hemisphere mid- to highlatitudes by $1-7 \%$ with maximum overestimates in polar winter.

The model underestimate $\left(5 \%\right.$ ) of $\Delta^{17} \mathrm{O}$ (nitrate) maximizes in polar regions in spring when nitrate formation from $\mathrm{BrONO}_{2}$ hydrolysis is expected to be significant (Morin et al., 2007; Evans et al., 2003; Saiz-Lopez et al., 2008). $\mathrm{BrO}$ radical concentrations can be as high as $\sim 30$ ppt during spring in both the Arctic and Antarctic close to seaice (Chance, 1998; Richter et al., 1997; Wagner and Platt, 1998; Kreher et al., 1997). Several indirect lines of evidence suggest a non-negligible contribution of bromine radical chemistry in the inland Arctic (Summit, Greenland) during summer months (Grannas et al., 2007; Peterson and Honrath, 2001; Sjostedt et al., 2007), and are supported by $\mathrm{BrO}$ observations of 1-3 ppt during early summer at Summit, Greenland (Huey et al., 2007). The model underestimate of $\Delta^{17} \mathrm{O}$ (nitrate) in the polar-regions during spring is likely due to the lack of BrO chemistry in the model, which may also contribute to the underestimate in summer. Kunasek et al. (2008) estimated a 4\%o increase in summertime $\Delta^{17} \mathrm{O}$ (nitrate) at Summit, Greenland after adding reactive bromine chemistry to their box model assuming $\mathrm{BrO}$ concentrations of 3 ppt. This suggests that $\mathrm{BrO}$ chemistry can fully account for the $3 \%$ underestimate in calculated $\Delta^{17} \mathrm{O}$ (nitrate) at Summit in July (Fig. 5). In addition, photochemical processing of snowpack nitrate during spring and summer leads to a significant local source of $\mathrm{NO}_{\mathrm{x}}$ in the polar-regions (Jones et al., 2000; Honrath et al., 2002) that is not accounted for in the model. Local reprocessing of previously deposited nitrate during periods of active bromine radical chemistry will enhance the importance of bromine in $\mathrm{NO}_{\mathrm{x}}$ cycling and nitrate formation in the polar-regions.

Non-zero $\Delta^{17} \mathrm{O}(\mathrm{OH})$ values due to incomplete exchange of $\mathrm{OH}$ with water vapor in the cold, dry polar atmosphere (Morin et al., 2007) may also contribute to the underestimate of $\Delta^{17} \mathrm{O}$ (nitrate) in winter and spring. Kunasek et al. (2008) estimated that $\sim 10 \%$ of the original $\Delta \Delta^{17} \mathrm{O}(\mathrm{OH})$ could be retained at Summit, Greenland in spring and summer. This would lead to a maximum underestimate of 1$2 \%$ in calculated $\Delta^{17} \mathrm{O}$ (nitrate) and may partially explain the spring/summer discrepancy in polar regions.

The model tends to overestimate $\Delta^{17} \mathrm{O}$ (nitrate) $(1-7 \%$ ) in the northern mid-to high latitudes in winter when $\mathrm{N}_{2} \mathrm{O}_{5}$ hydrolysis dominates nitrate production (Fig. 4), suggesting that the model may be overestimating this nitrate production pathway. The reaction probability of $\mathrm{N}_{2} \mathrm{O}_{5}\left(\gamma_{\mathrm{N}_{2} \mathrm{O}_{5}}\right)$ on the surface of aerosols is influenced by temperature, humidity, and aerosol composition (Kane et al., 2001; Hallquist et al., 2003; Thornton et al., 2003). Davis et al. (2008) suggested that $\gamma_{\mathrm{N}_{2} \mathrm{O}_{5}}$ may be overestimated by Evans and 
Jacob (2005) (used in GEOS-Chem), especially in regions of relatively low temperatures and high relative humidity. In addition, the presence of aerosol surface coating by organics has been shown to decrease $\gamma_{\mathrm{N}_{2} \mathrm{O}_{5}}$ (McNeill et al., 2006) and is not accounted for in the model. We examine the sensitivity of $\Delta^{17} \mathrm{O}$ (nitrate) to $\mathrm{N}_{2} \mathrm{O}_{5}$ hydrolysis by setting the reaction probability of $\mathrm{N}_{2} \mathrm{O}_{5}$ equal to zero $\left(\gamma_{\mathrm{N}_{2}} \mathrm{O}_{5}=0\right)$, effectively shutting off this nitrate formation pathway. Removing $\mathrm{N}_{2} \mathrm{O}_{5}$ hydrolysis results in relative increase in both $\mathrm{NO}_{2}+\mathrm{OH}$ (Reaction R5) and $\mathrm{NO}_{3}+\mathrm{DMS} / \mathrm{HC}$ (Reactions R6, R7), with the former (latter) reaction becoming more important in the tropics and mid-latitudes in summer (mid- to high-latitudes in winter). This tends to increase surface $\Delta^{17} \mathrm{O}$ (nitrate) by up to $7 \%$ (seasonal mean) in regions where nighttime reactions dominate (mid- to high-latitudes in winter), and decrease surface $\Delta^{17} \mathrm{O}$ (nitrate) by up to $3 \%$ (seasonal mean) in regions where daytime reactions dominate (tropics, midlatitudes in summer). Removing $\mathrm{N}_{2} \mathrm{O}_{5}$ hydrolysis results in a $30 \%$ increase in the global, annual-mean tropospheric NOX $\left(=\mathrm{NO}+\mathrm{NO}_{2}+\mathrm{NO}_{3}+\mathrm{HNO}_{2}+2 \mathrm{~N}_{2} \mathrm{O}_{5}+\mathrm{HNO}_{4}\right)$ burden. This effect of $\mathrm{N}_{2} \mathrm{O}_{5}$ hydrolysis on reactive nitrogen partitioning and loss is consistent with, but somewhat smaller than that found by an earlier analysis (50\%) (Dentener and Crutzen, 1993), likely due to the different $\gamma_{\mathrm{N}_{2} \mathrm{O}_{5}}$ values used.

The model overestimates $\Delta^{17} \mathrm{O}$ (nitrate) at Princeton, NJ year round by $4-7 \%$ and at Bermuda by $1-5 \%$. These data sets represent event-based rainwater samples averaged over each month of collection and thus may not adequately represent the monthly-mean state. These observations may also be influenced by the presence of soluble organic nitrates, which are not included in the model calculations.

Given that the denitrifier method may be measuring a combination of organic and inorganic nitrates, we examine the potential influence of soluble organic nitrates by including them in our isotope calculations. Soluble organic nitrates included in our isotope calculations form in the model mainly from reactions of $\mathrm{NO}+\mathrm{RO}_{2}$ to form isoprene nitrates $\left(\mathrm{RONO}_{2}\right)$, where $\mathrm{RO}_{2}$ in this case originates from isoprene oxidation products. Soluble organic nitrates also form to a minor extent from reactions between isoprene nitrates (formed via isoprene $+\mathrm{NO}_{3}$ ) and $\mathrm{RO}_{2}$ (methylperoxy and peroxyacetyl radicals). Isoprene is a biogenic hydrocarbon whose main source is terrestrial vegetation, with emissions largely dependent upon vegetation type and density, light and temperature (Guenther et al., 1995). We use the Model of Emissions from Gases and Aerosols in Nature (MEGAN) to compute process-based biogenic emissions of isoprene and other trace gases (Guenther et al., 2006) as described in Palmer et al. (2006) and Millet et al. (2008). The model does not include soluble organic nitrates formed via oxidation of anthropogenic hydrocarbons in the presence of $\mathrm{NO}_{\mathrm{x}}$, which would most impact the formation of organic nitrates during winter when emission rates for biogenic hydrocarbons are low. The model treats soluble organic nitrates in a similar manner to inorganic nitrate, partitioning the organic nitrates between the gas and aerosol-phase according to thermodynamic equilibrium of $\mathrm{HNO}_{3}$. Organic nitrates are then dry or wet deposited. The formation of organic nitrates is most important in regions where isoprene emissions are highest (forested regions in the low- to mid-latutides, maximum in summer).

The $\Delta^{17} \mathrm{O}$ value of organic nitrates is calculated according to the following, for reactions with $\mathrm{NO}+\mathrm{RO}_{2}$ and isoprene nitrates $+\mathrm{RO}_{2}$, respectively:

$$
\begin{aligned}
& \Delta^{17} \mathrm{O}\left(\mathrm{RONO}_{2}\right)_{\mathrm{NO}+\mathrm{RO}_{2}}=1 / 3 A_{\text {day }} \Delta^{17} \mathrm{O}\left(\mathrm{O}_{3}\right) \\
& \Delta^{17} \mathrm{O}\left(\mathrm{RONO}_{2}\right)_{\mathrm{NO}_{3}+\mathrm{RO}_{2}}=2 / 3 A_{\text {night }} \Delta^{17} \mathrm{O}\left(\mathrm{O}_{3}\right)
\end{aligned}
$$

For the latter reaction, we assume that the organic nitrate retains two of the original oxygen atoms of $\mathrm{NO}_{3}$, which may be an underestimate. However, our results are not particularly sensitive to this assumption since organic nitrates formed via this reaction pathway are a minor source of total (inorganic plus organic) nitrate ( $<6 \%$ annual mean). Organic nitrates formed via the $\mathrm{NO}+\mathrm{RO}_{2}$ pathway dominate (80\% annual mean) total nitrate in tropical forested regions, and are as high as 20\% (annual mean) elsewhere. Model results that include organic plus inorganic nitrate in calculations of $\Delta^{17} \mathrm{O}$ (nitrate) are shown in Fig. 5 for the observations that utilized the denitrifier method. Including organic nitrates derived from isoprene oxidation lowers the calculated $\Delta{ }^{17} \mathrm{O}$ (nitrate) values by as much as $3 \%$ at a midlatitude continental location (Princeton, NJ) during summer, and as much as $10 \%$ in tropical forested regions.

The overestimate of $\Delta^{17} \mathrm{O}$ (nitrate) in the polar winter (2$7 \%$ ) can be explained by the use of local $A$ values in calculating $\Delta^{17} \mathrm{O}$ (nitrate) where there is a negligible local source of $\mathrm{NO}_{\mathrm{x}}$ and most of the nitrate originates from lower latitudes. The importance of ozone in $\mathrm{NO}_{\mathrm{x}}$ cycling shows strong latitudinal dependence resulting in $A$ values increasing with latitude (maximum in polar winter). The overestimate of $\Delta^{17} \mathrm{O}$ (nitrate) due to the use of local $A$ values is most pronounced in remote polar-regions in winter where nitrate originates from lower latitudes and local $\mathrm{NO}_{\mathrm{x}}$ production (e.g. snowpack photodenitrification) is absent. An overestimate of the $A_{\text {day }}$ value by 0.2 and $A_{\text {night }}$ by 0.1 (typical differences between $A$ values at $90^{\circ} \mathrm{S}$ and $45^{\circ} \mathrm{S}$ ), leads to an overestimate of $\Delta{ }^{17} \mathrm{O}$ (nitrate) by $4-5 \%$ (accounting for the $20-40 \%$ contribution of (Reaction R5) to total nitrate concentrations at the surface in polar winter). This is within the range of the overestimate in polar winter.

\section{Conclusions}

We use the global 3-D chemical transport model, GEOSChem, to simulate the oxygen isotopic composition $\left(\Delta^{17} \mathrm{O}\right)$ of atmospheric nitrate and compare with available observations. These comparisons allow for quantitative assessment 
of the relative importance of different oxidants in $\mathrm{NO}_{\mathrm{x}} \mathrm{cy}-$ cling and nitrate formation pathways, and are critical for interpreting ice core observations of $\Delta^{17} \mathrm{O}$ (nitrate) in terms of changes in past oxidant concentrations (Alexander et al., 2004).

The largest uncertainty for calculations of $\Delta^{17} \mathrm{O}$ (nitrate) is the unconstrained variability in tropospheric $\Delta^{17} \mathrm{O}\left(\mathrm{O}_{3}\right)$. The best agreement with global observations occurs when assuming $\Delta{ }^{17} \mathrm{O}\left(\mathrm{O}_{3}\right)=35 \%$ and using the Savarino et al. (2008) isotopic transfer function during the reaction of $\mathrm{O}_{3}$ with $\mathrm{NO}$ and $\mathrm{NO}_{2}$. The spatial variability of $\Delta^{17} \mathrm{O}$ (nitrate) is largely determined by the importance of $\mathrm{O}_{3}$ in $\mathrm{NO}_{\mathrm{x}}$ cycling due to the fact that the isotopic composition of two-thirds of the oxygen atoms of nitrate is determined during $\mathrm{NO}_{\mathrm{x}} \mathrm{cy}-$ cling. The oxidation pathway of $\mathrm{NO}_{\mathrm{x}}$ to $\mathrm{HNO}_{3}$ plays a secondary but significant role in determining $\Delta^{17} \mathrm{O}$ (nitrate) values. The global, annual-mean tropospheric inorganic nitrate burden $(0.38 \mathrm{Tg} \mathrm{N})$ is dominated by nitrate formation via $\mathrm{NO}_{2}+\mathrm{OH}(76 \%)$, followed by $\mathrm{N}_{2} \mathrm{O}_{5}$ hydrolysis (18\%) and $\mathrm{NO}_{3}+\mathrm{DMS} / \mathrm{HC}(4 \%)$.

Calculated values of annual-mean $\Delta^{17} \mathrm{O}$ (nitrate) in the lowest model layer (0-200 $\mathrm{m}$ above the surface) vary from $7 \%$ in the tropics to $41 \%$ in polar regions. Modeled annualmean $\Delta^{17} \mathrm{O}$ (nitrate) values as high as $40 \%$ o exist in the polar regions with negligible contribution from stratospheric nitrate $(<2 \%)$. Modeled annual-mean $\Delta^{17} \mathrm{O}$ (nitrate) values as low as $7 \% \circ$ are predicted in tropical forested regions due to the dominance of peroxy radicals and $\mathrm{OH}$ in $\mathrm{NO}_{\mathrm{x}}$ cycling and nitrate formation, respectively. Additional measurements of $\Delta^{17} \mathrm{O}$ (nitrate) in the tropics are needed to validate these results.

The largest model discrepancies are in polar-regions during spring and summer (0-5\%o underestimate), and in midto high latitudes in winter (1-7\%o overestimate). The former is likely due to the lack of reactive bromine chemistry in the model, which should peak in spring in polar regions and lead to large ( $>40 \%$ o $) \Delta{ }^{17} \mathrm{O}$ (nitrate) (Morin et al., 2007). The high bias in polar winter is due to the use of the local fractional importance of $\mathrm{O}_{3}$ (versus $\mathrm{HO}_{2}+\mathrm{RO}_{2}$ ) in $\mathrm{NO}_{\mathrm{x}}$ cycling ( $A$ value) for calculations of $\Delta{ }^{17} \mathrm{O}$ (nitrate) in regions where nitrate originates from lower latitudes. This overestimate is particularly pronounced in winter when local $\mathrm{NO}_{\mathrm{x}}$ production (e.g., snowpack photodenitrification) is negligible. The role (or lack thereof) of organic nitrates in observations of $\Delta^{17} \mathrm{O}$ (nitrate) that utilize the denitrifier method (Kaiser et al., 2007; Casciotti et al., 2002) needs to be assessed. Whether or not organic nitrates are included in the calculation of $\Delta^{17} \mathrm{O}$ (nitrate) has a significant impact in lowto mid-latitude continental regions, and may partially account for the high bias in the mid-latitude $\Delta^{17} \mathrm{O}$ (nitrate) values.

\section{Supplemental information}

Please find the supplemental material at http://www.atmos-chem-phys.net/9/5043/2009/ acp-9-5043-2009-supplement.pdf.

Acknowledgements. We gratefully acknowledge funding of the COCA cruise by the Spanish Ministry of Science and Innovation, and financial support for this project from the NSF Atmospheric Chemistry Program under grant NSF-ATM 0607846 to B. Alexander. M. G. Hastings acknowledges partial support from the Joint Institute for the Study of the Atmosphere and Ocean (JISAO) under NOAA cooperative agreement No. NA17RJ1232 (contribution \#1761). We thank Dean Hegg and Andrew Schauer for assistance with nitrate concentration and isotopic measurements, respectively, for the COCA samples, and Lauren Brothers for sharing her data from Ecuador.

Edited by: T. Röckmann

\section{References}

Alexander, B., Savarino, J., Kreutz, K. J., and Thiemens, M. H.: Impact of preindustrial biomass-burning emissions on the oxidation pathways of tropospheric sulfur and nitrogen, J. Geophys. Res., 109, D08303, doi:10.1029/2003JD004218, 2004.

Alexander, B., Savarino, J., Lee, C. C. W., Park, R. J., Jacob, D. J., Li, Q., Yantosca, R. M., and Thiemens, M. H.: Sulfate formation in sea-salt aerosols: Constraints from oxygen isotopes, J. Geophys. Res., 110, D10307, doi:10.1029/2004JD005659, 2005.

Benkovitz, C.M., Schultz, M. T., Pacyna, J., Tarrason, L., Dignon, J., Voldner, E. C., Spiro, P. A., Logan, J. A., and Graedel, T. E.: Global, gridded inventories for anthropogenic emissions of sulfur and nitrogen, J. Geophys. Res., 101, 29239-29253, 1996.

Bey, I., Jacob, D. J., Yantosca, R. M., Logan, J. A., Field, B. D., Fiore, A. M., Li, Q., Liu, H. Y., Mickley, L. J., and Schultz, M. G.: Global modeling of tropospheric chemistry with assimilated meteorology: Model description and evaluation, J. Geophys. Res., 106(D19), 23073-23095, 2001.

Bhattacharya, S. K., Pandey, A., and Savarino, J.: Determination of intramolecular isotope distribution of ozone by oxidation reaction with silver metal, J. Geophys. Res, 113, D03303, doi:10.1029/2006JF008309, 2008.

Brothers, L. A., Dominguez, G., Fabian, P., and Thiemens, M. H.: Using multi-isotope tracer methods to understand the sources of nitrate in aerosols, fog and river water in Podocarpus National Forest, Ecuador, Eos Trans. AGU, 89, Abstract A11C0136, 2008.

Brown, S. S., Dube, W. P., Fuchs, H., Ryerson, T. B., Wollny, A. G., Brock, C. A., Bahreini, R., Middlebrook, A. M., Neuman, J. A., Atlas, E., Roberts, J. M., Osthoff, H. D., Trainer, M., Fehsenfeld, F. C., and Ravishankara, A. R.: Reactive uptake coefficients for $\mathrm{N}_{2} \mathrm{O}_{5}$ determined from aircraft measurements during the Second Texas Air Quality Study: Comparison to current model parameterizations, J. Geophys. Res, 114, D00F10, doi:10.1029/2008JD011679, 2009.

Carpenter, L. J., Monks, P. S., Bandy, B. J., and Penkett, S. A.: A study of peroxy radicals and ozone photochemistry at coastal 
sites in the northern and southern hemispheres, J. Geophys. Res, 102, 25417-25427, 1997.

Casciotti, K.L., Sigman, D. M., Hastings, M. G., Bohlke, K. K., and Hilkert, A.: Measurement of the oxygen isotopic composition of nitrate in seawater and freshwater using the denitrifier method, Anal. Chem., 74, 4905-4912, 2002.

Chance, K.: Analysis of BrO Measurements from the Global Ozone Monitoring Experiment, Geophys. Res. Lett., 25, 3335-3338, 1998.

Dachs, J., Calleja, M. L., Duarte, C. M., Vento, S. d., Turpin, B., Polisori, A., Herndl, G. J., and Agusti, S.: High atmosphereocean exchange of organic carbon in the NE subtropical Atlantic, Geophys. Res. Lett., 32, L21807, doi:10.1029/2005GL023799, 2005.

Davis, J. M., Bhave, P. V., and Foley, K. M.: Parameterization of $\mathrm{N}_{2} \mathrm{O}_{5}$ reaction probabilities on the surface of particles containing ammonium, sulfate, and nitrate, Atmos. Chem. Phys., 8, 52955311, 2008,

http://www.atmos-chem-phys.net/8/5295/2008/.

DeMore, B., W., Sander, S. P., Golden, D. M., Hampson, R. F., Kurylo, M. J., Howard, C. J., Ravishankara, A. R., Kolb, C. E., and Molina, M. J.: Chemical kinetics and photochemical data for use in stratospheric modeling, JPL Publ., 97-4, 1-278., 1997.

Dentener, F. J., and Crutzen, P. J.: Reaction of $\mathrm{N}_{2} \mathrm{O}_{5}$ on tropospheric aerosols: Impact on the global distributions of $\mathrm{NO}_{\mathrm{x}}, \mathrm{O}_{3}$, and OH, J. Geophys. Res, 98, 7149-7163, 1993.

Duarte, C. M., Dachs, J., Llabres, M., ALonso-Laita, P., Gasol, J. M., Tovar-Sanchez, A., Sanudo-Wilhemy, S., and Agusti, S.: Aerosol inputs enhance new production in the subtropical northeast Atlantic, J. Geophys. Res, 111, G04006, doi:10.1029/2005JG000140, 2006.

Dubey, M.K., Mohrschladt, R., Donahue, N. M., and Anderson, J. G.: Isotope-specific kinetics of hydroxyl radical $(\mathrm{OH})$ with water $\left(\mathrm{H}_{2} \mathrm{O}\right)$ : Testing models of reactivity and atmospheric fractionation, J. Phys. Chem. A., 101, 1494-1500, 1997.

Evans, M. J., Jacob, D. J., Atlas, E., Cantrell, C. A., Eisele, F., Flocke, F., Fried, A., Mauldin, R. L., Ridley, B. A., Wert, B., Talbot, R., Blake, D., Heikes, B., Snow, J., Walega, J., Weinheimer, A. J., and Dibb, J.: Coupled evolution of $\mathrm{BrO}_{\mathrm{x}}-\mathrm{ClO}_{\mathrm{x}}-$ $\mathrm{HO}_{\mathrm{x}}-\mathrm{NO}_{\mathrm{x}}$ chemistry during bromine-catalyzed ozone depletion events in the arctic boundary layer, J. Geophys. Res, 108, 8368, doi:10.1029/2002JD002732, 2003.

Evans, M. J. and Jacob, D. J.: Impact of new laboratory studies of $\mathrm{N}_{2} \mathrm{O}_{5}$ hydrolysis on global model budgets of tropospheric nitrogen oxides, ozone, and $\mathrm{OH}$, Geophys. Res. Lett., 32, L09813, doi:10.1029/2005GL022469, 2005.

Ewing, A., S., Michalski, G., Thiemens, M., Quinn, C., R., Macalady, L., J., Kohl, S., Wankel, D., S., Kendall, C., McKay, P., and Amundson, C. R.: Rainfall limit of the N cycle on Earth, Global Biogeochemical Cycles, 21(12), GB3009, doi:10.1029/2006gb002838, 2007.

Fiore, A. M., Jacob, D. J., Bey, I., Yantosca, R. M., Field, B. D., and Wilkinson, J. G.: Background ozone over the United States in summer: Origin and contribution to pollution episodes, J. Geophys. Res, 107, 4275, doi:10.1029/2001JD000982, 2002.

Fiore, A. M., Jacob, D. J., Liu, H., Yantosca, R. M., Fairlie, T. D., and Li, Q.: Variability in surface ozone background over the United States: Implications for air quality policy, J. Geophys. Res, 108, 4787, doi:10.1029/2003JD003855, 2003.
Fleming, Z. L., Monks, P. S., Rickard, A. R., Heard, D. E., Bloss, W. J., Seakins, P. W., Still, T. J., Sommariva, R., Pilling, M. J., Morgan, R., Green, T. J., Brough, N., Mills, G. P., Penkett, S. A., Lewis, A. C., Lee, J. D., Saiz-Lopez, A., and Plane, J. M. C.: Peroxy radical chemistry and the control of ozone photochemistry at Mace Head, Irelend during the summer of 2002, Atm. Chem. Phys., 6, 2193-2214, 2006.

Fountoukis, C., and Nenes, A.: ISORROPIA II: a computationally efficient thermodynamic equilibrium model for $\mathrm{K}^{+}$ $\mathrm{Ca}^{2+}-\mathrm{Mg}^{2+}-\mathrm{NH}_{4}^{+}-\mathrm{Na}^{+}-\mathrm{SO}_{4}^{2-}-\mathrm{NO}_{3}^{-}-\mathrm{Cl}^{-}-\mathrm{H}_{2} \mathrm{O}$ aerosols, Atmos. Chem. Phys., 7, 4639-4659, 2007, http://www.atmos-chem-phys.net/7/4639/2007/.

Franz, P. and Röckmann, T.: High-precision isotope measurements of $\mathrm{H}_{2}^{16} \mathrm{O}, \mathrm{H}_{2}^{17} \mathrm{O}, \mathrm{H}_{2}^{18} \mathrm{O}$, and the $\Delta^{17} \mathrm{O}$-anomaly of water vapor in the southern lowermost stratosphere, Atmos. Chem. Phys., 5, 2949-2959, 2005, http://www.atmos-chem-phys.net/5/2949/2005/.

Galloway, N., J., Townsend, R., A., Erisman, Willem, J., Bekunda, Mateete, Cai, Zucong, Freney, R., J., Martinelli, A., L., Seitzinger, P., S., Sutton, and A., M.: Transformation of the Nitrogen Cycle: Recent Trends, Questions, and Potential Solutions, Science, 320, 889-892, doi:10.1126/science.1136674, 2008.

Gerber, H. E.: Relative-humidity paramaterization of the Nave aerosol model (NAM), Natl. Res. Lab., Washington, D.C., 1985.

Grannas, A. M., Jones, A. E., Dibb, J., Ammann, M., Anastasio, C., Beine, H. J., Bergin, M., Bottenheim, J., Boxe, C. S., Carver, G., Chen, G., Crawford, J. H., Dominé, F., Frey, M. M., Guzmán, M. I., Heard, D. E., Helmig, D., Hoffmann, M. R., Honrath, R. E., Huey, L. G., Hutterli, M., Jacobi, H. W., Klán, P., Lefer, B., McConnell, J., Plane, J., Sander, R., Savarino, J., Shepson, P. B., Simpson, W. R., Sodeau, J. R., Glasow, R. V., Weller, R., Wolff, E. W., and Zhu, T.: An overview of snow photochemistry: evidence, mechanisms and impacts, Atmos. Chem. Phys., 7, 43294373, 2007, http://www.atmos-chem-phys.net/7/4329/2007/.

Guenther, A., Hewitt, N., C., Erickson, D., Fall, R., Geron, C., Graedel, T., Harley, P., Klinger, L., Lerdau, ;, M., McKay, A., W., Pierce, T., Scholes, B., Steinbrecher, R., Tallamraju, R., Taylor, J., Zimmerman, and, and Mayewski, P. A.: A global model of natural volatile organic compound emissions, J. Geophys. Res., 100, 8873-8892, 1995.

Guenther, A., Karl, T., Harley, P., Wiedinmyer, C., Palmer, P. I., and Geron, C.: Estimates of global terrestrial isoprene emissions using MEGAN (Model of Emissions of Gases and Aerosols from Nature), Atmos. Chem. Phys., 6, 3181-3210, 2006, http://www.atmos-chem-phys.net/6/3181/2006/.

Hallquist, M., Stewart, D. J., Stephenson, S. K., and Cox, R. A.: Hydrolysis of $\mathrm{N}_{2} \mathrm{O}_{5}$ on sub-micron sulfate aerosol, Phys. Chem. Chem. Phys., 5, 3453-3463, 2003.

Hastings, M. G., Sigman, D. M., and Lipschultz, F.: Isotopic evidence for source changes of nitrate in rain at Bermuda, J. Geophys. Res., 108, 4790, doi:10.1029/2003JD003789, 2003.

Hauff, Karlheinz, Fischer, G., R., Ballschmiter, and Karlheinz: Determination of C1-C5 alkyl nitrates in rain, snow, white frost, lake, and tap water by a combined codistillation head-space gas chromatography technique, Determination of henry's law constants by head-space GC, Chemosphere, 37, 2599-2615, 1998.

Hawari, J., Halasz, A., Sheremata, T., Beaudet, S., Groom, C., Paquet, L., Rhofir, C., Ampleman, G., and Thiboutot, S.: Character- 
ization of metabolites during biodegradatin of hexahydro-1,3,5trinotro-1,3,5-triazine (RDX) with municipal anaerobic sludge, Appl. Environ. Microbiology, 66, 2652-2657, 2000.

Honrath, E., R., Lu, Y., Peterson, C., M., Dibb, E., J., Arsenault, A., M., Cullen, J., N., Steffen, and K.: Vertical fluxes of $\mathrm{NO}_{\mathrm{x}}$, $\mathrm{HONO}$, and $\mathrm{HNO}_{3}$ above the snowpack at Summit, Greenland, Atmos. Environ., 36, 2629-2640, 2002.

Hudman, R. C., Murray, L. T., Jacob, D. J., Turquety, S., Wu, S., Millet, D. B., Avery, M., Goldstein, A. H., and Holloway, J.: North American influence on tropospheric ozone and the effects of recent emission reductions: Constraints from ICARTT observations, J. Geophys. Res, 114, doi:10.1029/2008JD010126, 2009.

Huey, L. G., Dibb, J., Stutz, J., Brooks, S., Glasow, R. V., Lefer, B., Chen, G., Kim, S., and Tanner, D.: Observations of halogens at Summit, Greenland, EOS Transactions, AGU, 88, Fall Meet. Suppl., Abstract A42B-05, 2007.

Jacob, D. J.: Heterogeneous chemistry and tropospheric ozone, Atmos. Environ., 34, 2131-2159, 2000.

Jaegle, L., Steinberger, L., Martin, R. V., and Chance, K.: Global partitioning of $\mathrm{NO}_{\mathrm{x}}$ sources using satellite observations: Relative roles of fossil fuel combustion, biomass burning and soil emissions, Faraday Discuss., 130, 407-423, doi:10.1039/b502128f, 2005.

Janssen, C., Guenther, J., and Krankowsky, D.: Relative formation rates of ${ }^{50} \mathrm{O}_{3}$ and ${ }^{52} \mathrm{O}_{3}$ in ${ }^{16} \mathrm{O}-{ }^{18} \mathrm{O}$ mixtures, J. Chem. Phys., 111, 7179-7182, 1999.

Janssen, C.: Intramolecular isotope distribution in heavy ozone $\left({ }^{16} \mathrm{O}^{18} \mathrm{O}^{16} \mathrm{O}\right.$ and $\left.{ }^{16} \mathrm{O}^{16} \mathrm{O}^{18} \mathrm{O}\right)$, J. Geophys. Res., 110, D08308, doi:10.1029/2004JD005479, 2005.

Johnston, J. C. and Thiemens, M. H.: The isotopic composition of tropospheric ozone in three environments, J. Geophys. Res., 102, 25395-25404, 1997.

Jones, A. E., Weller, R., Wolff, E. W., and Jacobi, A. H.-W.: Speciation and rate of photochemical $\mathrm{NO}$ and $\mathrm{NO}_{2}$ production in Antarctic snow, Geophys. Res. Lett., 27, 345-348, 2000.

Kaiser, J., Hastings, M. G., Houlton, B. Z., Rockmann, T., and Sigman, D. M.: Triple Oxygen Isotope Analysis of Nitrate Using the Denitrifier Method and Thermal Decomposition of $\mathrm{N}_{2} \mathrm{O}$, Anal. Chem., 79, 599-607, 2007.

Kane, S. M., Caloz, F., and Leu, M. T.: Heterogeneous uptake of gaseous $\mathrm{N}_{2} \mathrm{O}_{5}$ by $\left(\mathrm{NH}_{4}\right)_{2} \mathrm{SO}_{4}, \mathrm{NH}_{4} \mathrm{HSO}_{4}$ and $\mathrm{H}_{2} \mathrm{SO}_{4}$ aerosol, J. Phys. Chem., 105, 6465-6570, 2001.

Krankowsky, D., Bartecki, F., Klees, G. G., Mauersberger, K., Schellenback, K., and Stehr, J.: Measurement of heavy isotope enrichment in tropospheric ozone, Geophys. Res. Lett., 22, 1713-1716, 1995.

Kreher, K., Johnson, P. V., Wood, S. W., Nardi, B., and Platt, U.: Ground-based measurements of tropspheric and stratospheric BrO at Arrivals Heights, Antarctica, Geophys. Res. Lett., 24, 3021-3024, 1997.

Kunasek, A., S., Alexander, B., Hastings, M. G., Steig, E. J., Gleason, D. J., and Jarvis, J. C.: Measurements and modeling of $\Delta^{17} \mathrm{O}$ of nitrate in a snowpit from Summit, Greenland, J. Geophys. Res. , 113, D24302, doi:10.1029/2008JD010103, 2008.

Legrand, M. R. and Kirchner, S.: Origins and variations of nitrate in south polar precipitation, J. Geophys. Res, 95, 3493-3507, 1990.

Levy, H., Moxim, W. J., Klonecki, A. A., and Kasibhatla, P. S.: Simulated tropospheric NOx: Its evaluation, global distribu- tion and individual source contributions, J. Geophys. Res., 104, 26279-226306, 1999.

Liang, M.-C., Irion, F. W., Weibel, J. D., Miller, C. E., Blake, G. A., and Yung, Y. L.: Isotopic composition of stratospheric ozone, J. Geophys. Res, 111, D02302, doi:10.1029/2005JD006342, 2006.

Liu, H., Jacob, D. J., Bey, I., and Yantosca, R. M.: Constraints from ${ }^{210} \mathrm{~Pb}$ and ${ }^{7} \mathrm{Be}$ on wet deposition and transport in a global threedimensional chemical tracer model driven by assimilated meterological fields, J. Geophys. Res., 106, 12109-112128, 2001.

Logan, J. A.: Nitrogen oxides in the troposphere: Global and regional budgets, J. Geophys. Res., 88, 785-807, 1983.

Lyons, J. R.: Transfer of mass-independent fractioation on ozone to other oxygen-containing molecules in the atmosphere, Geophys. Res. Lett., 28, 3231-3234, 2001.

Martin, R. V., Jacob, D. J., Yantosca, R. M., Chin, M., and Ginoux, P.: Global and regional decreases in tropospheric oxidants form photochemical effects of aerosols, J. Geophys. Res., 108, 4097, doi:10.1029/2002JD002622, 2003.

Martin, R. V., Jacob, D. J., Logan, J. A., Bey, I., Yantosca, R. M., Staudt, A. C., Li, Q. B., Fiore, A. M., Duncan, B. N., Liu, H., Ginoux, P., and Thouret, V.: Interpretation of TOMS observations of tropical tropospheric ozone with a global model and in-situ observations, J. Geophys. Res, 107, 4351, doi:10.1029/2001JD001480, 2002.

Matsuhisa, Y., Goldsmith, J. R., and Clayton, R. N.: Mechanisms of hydrothermal crystallization of quartz at $250 \mathrm{C}$ and $15 \mathrm{kbar}$, Geochim. Cosmochim. Acta, 42, 173-182, 1978.

Mauersberger, K., Erbacher, B., Krankowsky, D., Gunther, J., and Nickel, R.: Ozone isotope enrichment: Isotopomer-specific rate coefficients, Science, 283, 370-372, 1999.

Mauersberger, K., Lämmerzahl, P., and Krankowsky, D.: Stratospheric Ozone Isotope Enrichments - Revisited, Geophys. Res. Lett., 28, 3155-3158, 2001.

Mayewski, P.A., Lyons, W. B., Spencer, M. J., Twickler, M. S., Buck, C. F., and Whitlow, S.: An ice-core record of atmospheric response to anthropogenic sulphate and nitrate, Nature, 346, 554-556, 1990.

McCabe, J. R., Thiemens, M. H., and Savarino, J.: A record of ozone variability in South Pole Antarctic snow: Role of nitrate oxygen isotopes, J. Geophys. Res, 112, D12303, doi:10.1029/2006JD007822, 2007.

McMorrow, A., Ommen, T. D. V., Morgan, V., and Curran, M. A. J.: Ultra-high-resolution seasonality of trace-ion species and oxygen isotope ratios in Antarctic firn over four annual cycles, Ann. Glaciol., 39, 34-40, 2004.

McNeill, V. F., Patterson, J., Wolfe, G. M., and Thornton, J.: The Effect of Varying levels of Surfactant on the Reactive Uptake of $\mathrm{N}_{2} \mathrm{O}_{5}$ to Submicron Aqueous Aerosol, Atm. Chem. Phys., 6, 1635-1644, 2006.

Michalski, G. M., Savarino, J., Bohlke, J. K., and Thiemens, M. H.: Determination of the total oxygen isotopic composition of nitrate and the calibration of a $\Delta^{17} \mathrm{O}$ nitrate reference material, Anal. Chem., 74, 4989-4993, 2002.

Michalski, G. M., Scott, Z., Kabiling, M., and Thiemens, M. H.: First measurements and modeling of $\Delta^{17} \mathrm{O}$ in atmospheric nitrate, Geophys. Res. Lett., 30, 1870, doi:1810.1029/2003GL017015, 2003.

Michalski, G. and Bhattacharya, S. K.: The role of symmetry in the mass independent isotope effect in ozone, Proc. Natl. Acad. Sci., 
106, 5493-5496, 2009.

Millet, D. B., Jacob, D. J., Boersma, K. F., Fu, T.-M., Kurosu, T. P., Chance, K., Heald, C. L., and Guenther, A.: Spatial distribution of isoprene emissions from North America derived from formaldehyde column measurements by the OMI satellite sensor, J. Geophys. Res., 113, D02307, doi:10.1029/2007JD008950, 2008.

Morin, S., Savarino, J., Bekki, S., Gong, S., and Bottenheim, J. W.: Signature of Arctic surface ozone depletion events in the isotope anomaly $\left(\Delta^{17} \mathrm{O}\right)$ of atmospheric nitrate, Atmos. Chem. Phys., 6 , 6255-6297, 2007,

http://www.atmos-chem-phys.net/6/6255/2007/.

Morin, S., Savarino, J., Frey, M., M., Yan, N., Bekki, S., Bottenheim, W. J., and Martins, F. J. M.: Tracing the Origin and Fate of $\mathrm{NO}_{\mathrm{X}}$ in the Arctic Atmosphere Using Stable Isotopes in Nitrate, Science, 322, 730-732, doi:10.1126/science.1161910, 2008.

Morin, S., Savarino, J., Frey, M. M., Domine, F., Jacobi, H.-W., Kaleschke, L., and Martins, J. M. F.: Comprehensive isotopic composition of atmospheric nitrate in the Atlantic Ocean boundary layer from 65S to 79 N, J. Geophys. Res., 114, D05303, doi:10.1029/2008JD010696, 2009.

Morton, J., Barnes, J., Schueler, B., and Mauersberger, K.: Laboratory studies of heavy ozone, J. Geophys. Res., 95, 901-907, 1990.

Mulvaney, R. and Wolff, E. W.: Evidence for Winter/Spring Denitrification of the Stratosphere in the Nitrate Record of Antarctic Firn Cores, J. Geophys. Res., 98, 5213-5220, 1993.

Palmer, P. I., Abbot, D. S., Fu, T.-Z., Jacob, D. J., Chance, K., Kuruso, T. P., Guenther, A., Wiedinmyer, C., Stanton, J. C., Pilling, M. J., Pressley, S. N., Lamb, B., and Sumner, A. L.: Quantifying the seasonal and interannual variability of North American isoprene emissions using satellite observations of formaldehyde column, J. Geophys. Res., 111, D12315, doi:10.1029/2005JD006689, 2006.

Park, R.J., Jacob, D. J., Field, B. D., Yantosca, R. M., and Chin, M.: Natural and transboundary pollution influences on sulfate-nitrate-ammonium aerosols in the United States: implications for policy, J. Geophys. Res., 109, D15204, doi:10.1029/2003JD004473, 2004.

Peterson, M. C. and Honrath, R. E.: Observations of Rapid Photochemical Destruction of Ozone in Snowpack Interstitial Air, Geophys. Res. Lett., 28, 511-514, 2001.

Pickering, K. E., Wang, Y. S., Tao, W. K., Price, C., and Muller, J. F.: Vertical distributions of lightning $\mathrm{NO}_{\mathrm{x}}$ for use in regional and global chemical transport models, J. Geophys. Res., 103, 31203231216, 1998.

Prather, M. and Ehhalt, D.: Atmospheric chemistry and greenhouse gases, in: Climate Change 2001: The Scientific Basis. Contribution of Working Group I to the Third Assessment Report of the Intergovernmental Panel on Climate Change, edited by: Houghton, J. T., Ding, Y., Griggs, D. J., Noguer, M., van der Linden, P. J., Dai, X., Maskell, K., and Johnson, C. A., Cambridge University Press, Cambridge, United Kingdom and New York, NY, USA, 881 pp.

Price, C. and Rind, D.: A simple lightning parameterization for calculating global lightning distribution, J. Geophys. Res., 97, 9919-9933, 1992.

Randerson, J. T., vanderWerf, G. R., Giglio, L., Collatz, G. J., and Kasibhatla, P. S.: Global Fire EMissions Database,
Version 2 (GFEDv2.1). Data set. Available on line. [http: //daac.ornl.gov/] from Oak Ridge National Laboratory Distributed Active Archive Center, Oak Ridge, Tennessee, USA, doi:10.3334/ORNLDAAC/849, 2007.

Richter, A., Wittrock, F., Eisinger, M., and Burrows, J. P.: GOME observations of tropospheric $\mathrm{BrO}$ in northern hemispheric spring and summer 1997, Geophys. Res. Lett., 25, 2683-2686, 1997.

Saiz-Lopez, A., Plane, J. M. C., Mahajan, A. S., Anderson, P. S., Barguitte, S. J.-B., Jones, A. E., Roscoe, H. K., Salmon, R. A., Bloss, W. J., Lee, J. D., and Heard, D. E.: On the vertical distribution of boundary layer halogens over coastal Antarctica: implications for $\mathrm{O}_{3}, \mathrm{HO}_{\mathrm{x}}, \mathrm{NO}_{\mathrm{x}}$ and the $\mathrm{Hg}$ lifetime, Atm. Chem. Phys., 8, 887-900, 2008.

Sander, S. P., Friedl, R. R., Ravishankara, A. R., Golden, D. M., Kolb, C. E., Kurylo, M. J., Huie, R. E., Orkin, V. L., Molina, M. J., Moortgat, G. K., and Finlayson-Pitts, B. J.: Chemical kinetics and photochemical data for use in atmospheric studies, NASA Jet Propulsion Lab, 02-25, 2000.

Savarino, J., Kaiser, J., Morin, S., Sigman, D. M., and Thiemens, M. H.: Nitrogen and oxygen isotopic constraints on the origin of atmospheric nitrate in coastal Antarctica, Atmos. Chem. Phys., 7, 1925-1945, 2007, http://www.atmos-chem-phys.net/7/1925/2007/.

Savarino, J. and Thiemens, M. H.: Mass-independent oxygen isotope $\left({ }^{16} \mathrm{O},{ }^{17} \mathrm{O},{ }^{18} \mathrm{O}\right)$ fractionation found in $\mathrm{H}_{\mathrm{X}}, \mathrm{O}_{\mathrm{X}}$ reactions, $\mathrm{J}$. Phys. Chem., 103, 9221-9229, 1999a.

Savarino, J. and Thiemens, M. H.: Analytical procedure to determine both $\delta^{18} \mathrm{O}$ and $\delta^{17} \mathrm{O}$ of $\mathrm{H}_{2} \mathrm{O}_{2}$ in natural water and first measurements, Atmos. Env., 33, 3683-3690, 1999 b.

Savarino, J., Bhattacharya, S. K., Morin, S., Baroni, M., and Doussin, J.-F.: The $\mathrm{NO}+\mathrm{O}_{3}$ reaction: A triple oxygen isotope perspective on the reaction dynamics and atmospheric implications for the transfer of the ozone isotope anomaly, J. Chem. Phys., 128(19), 194303, doi:10.1063/1.2917581, 2008.

Schneider, H. R., Jones, D. B. A., McElroy, M. B., and Shi, G.-Y.: Analysis of residual mean transport in the stratosphere 1. Model description and comparison with satellite data, J. Geophys. Res., 105, 19991-920011, 2000.

Sjostedt, S. J., Huey, L. G., Tanner, D. J., Peischl, J., Chen, G., Dibb, J. E., Lefer, B., Hutterli, M. A., Beyersdorf, A. J., Blake, N. J., Blake, D. R., Sueper, D., Ryerson, T., Burkhart, J., and Stohl, A.: Observations of hydroxyl and the sum of peroxy radicals at Summit, Greenland during summer 2003, Atmos. Environ., 41, 5122-5137, 2007.

Stroud, C., Madronich, S., Atlas, E., Ridley, B., Flocke, F., Weinheimer, A., Talbot, B., Fried, A., Wert, B., Shetter, R., Lefer, B., Coffey, M., Heikes, B., and Blake, D.: Photochemistry in the arctic free troposphere: $\mathrm{NO}_{\mathrm{x}}$ budget and the role of odd nitrogen reservoir recycling, Atmos. Environ., 37, 3351-3364, 2003.

Terao, Y., Logan, J. A., Douglass, A. R., and Stolarski, R. S.: Contribution of stratospheric ozone to the interannual variability of tropospheric ozone in the northern extratropics, J. Geophys. Res, 113, D18309, doi:10.1029/2008JD009854, 2008.

Thompson, A. M.: The oxidizing capacity of the Earth's atmosphere: Probable past and future changes, Science, 256, 11571165, 1992.

Thornton, J. A., Braban, C. F., and Abbatt, J. P. D.: $\mathrm{N}_{2} \mathrm{O}_{5}$ hydrolysis on sub-micron organic aerosol: The effect of relative humidity, particle phase and particle size, Phys. Chem. Chem. Phys., 5, 
4593-4603, 2003.

Tie, X., Emmons, L., Horowitz, L., Brasseur, G., Ridley, B., Atlas, E., Stround, C., Hess, P., Klonecki, A., Madronich, S., Talbot, R., and Dibb, J.: Effect of sulfate aerosol on tropospheric NOx and ozone budgets: Model simulations and TOPSE evidence, J. Geophys. Res., 108, 8364, doi:10/10.1029/2001JD001508, 2003.

van der Werf, G. R., Randerson, J. T., Giglio, L., Collatz, G. H., and Kasibhatla, P. S.: Interannual variability in global biomass burning emission from 1997 to 2004, Atm. Chem. Phys., 6, 34233411, 2006.

Wagenbach, D., Legrand, M., Fischer, H., Pichlmayer, F., and Wolff, E. W.: Atmospheric near-surface nitrate at coastal Antarctic sites, J. Geophys. Res, 103, 11007-11020, 1998.

Wagner, T. and Platt, U.: Satellite mapping of enhanced BrO concentrations in the troposphere, Nature, 395, 486-490, 1998.

Wang, Y. H., Jacob, D. J., and Logan, J. A.: Global simulation of tropospheric $\mathrm{O}_{3}-\mathrm{NOx}$ hydrocarbon chemistry 1 . Model formulation, J. Geophys. Res., 103, 10713-10725, 1998.

Wang, H., Jacob, D. J., Sager, P. L., Streets, D. G., Park, R. J., Gilliland, A. B., and Donkelaar, A. V.: Surface ozone background in the United States: Canadian and Mexican pollution influences, Atmos. Environ., 43, 1310-1319, 2009.

Wang, J. S., McElroy, M. B., Logan, J. A., Palmer, P. I., Chameides, W. L., Wang, Y., and Megretskaia, I. A.: A quantitative assessment of uncertainties affecting estimates of global mean $\mathrm{OH}$ derived from methyl chloroform observations, J. Geophys. Res., 113, D12302, doi:10.1029/2007JD008496, 2008.

Weller, R., Jones, A. E., Wille, A., Jacobi, H.-W., McIntyre, H. P., Sturges, W. T., Huke, M., and Wagenbach, D.: Seasonality of reactive nitrogen oxides (NOy) at Neumayer Station, Antarctica, J. Geophys. Res., 107, 4673, doi:10.1029/2002JD002495, 2002.

Wesely, M. L.: Parameterization of surface resistances to gaseous dry deposition in regional-scale numerical-models, Atmos. Envion., 23, 1293-1304, 1989.
Wild, O., Zhu, Q., and Prather, M. J.: Fast-J: Accurate simulation of in- and below-cloud photolysis in global chemical models, J. Atm. Chem., 37, 245-282, 2000.

Wu, S., Mickley, L. J., Jacob, D. J., Logan, J. A., Yantosca, R. M., and Rind, D.: Why are there large differences between models in global budgets of tropospheric ozone?, J. Geophys. Res, 112, D05302, doi:10.1029/2006JD007801, 2007.

Yang, X., Cox, R. A., Warwick, N. J., Pyle, J. A., Carver, G. D., O'Connor, F. M., and Savage, N. H.: Tropospheric bromine chemistry and its impact on ozone: A model study, J. Geophys. Res., 110, D2331, doi:10.1029/2005JD003244, 2005.

Yienger, J. J. and Levy, H.: Empirical model of global soil-biogenic $\mathrm{NO}_{\mathrm{x}}$ emissions, J. Geophys. Res., 100, 11447-11464, 1995.

Zahn, A., Franz, P., Bechtel, C., Groob, J.-U., and Rockmann, T.: Modelling the budget of middle atmospheric water vapour isotopes, Atm. Chem. Phys., 6, 2073-2090, 2006.

Zhang, L., Gong, S., Padro, J., and Barrie, L.: A size-segregated particle dry deposition scheme for an atmosopheric aerosol module, Atmos. Environ., 35, 549-560, 2001.

Zhang, L., Jacob, D. J., Boersma, K. F., Jaffe, D. A., Olson, J. R., Bowman, K. W., Worden, J. R., Thompson, A. M., Avery, M. A., Cohen, R. C., Dibb, J. E., Flock, F. M., Fuelberg, H. E., Huey, L. G., McMillan, W. W., Singh, H. B., and Weinheimer, A. J.: Transpacific transport of ozone pollution and the effect of recent Asian emission increases on air quality on Notrh America: an integrated analysis using satellite, aircraft, ozonesonde, and surface observations, Atmos. Chem. Phys., 8, 6117-6136, 2008, http://www.atmos-chem-phys.net/8/6117/2008/. 